\title{
Allochthonous red pigments used in burial practices at the Copper Age site of Valencina de la Concepción (Sevilla, Spain): characterisation and social dimension
}

Miguel Ángel Rogerio-Candelera ${ }^{1}$, Liz Karen Herrera ${ }^{1}$, Ana Zélia Miller ${ }^{2}$, Leonardo García Sanjuán $^{3}$, Coronada Mora Molina ${ }^{3}$, David W. Wheatley ${ }^{4}$, Ángel Justo ${ }^{5}$ and Cesareo Saiz-Jimenez ${ }^{1}$

${ }^{1}$ Instituto de Recursos Naturales y Agriobiología de Sevilla (IRNAS-CSIC), Avda. Reina Mercedes, 10, 41012 Seville, Spain.

${ }^{2}$ Centro de Petrologia e Geoquímica, Instituto Superior Técnico, Av. Rovisco Pais, 1049-001 Lisbon, Portugal.

${ }^{3}$ Department of Prehistory and Archaeology, University of Seville, Maria de Padilla, $s / n, 41004$ Seville, Spain.

${ }^{4}$ Department of Archaeology. University of Southampton, Southampton SO17 1BF, United Kingdom.

${ }^{5}$ Instituto de Ciencia de Materiales de Sevilla (ICMSE-CSIC), Avda. Americo Vespucio, s/n, 41092 Seville, Spain.

\begin{abstract}
:
The use of red pigments linked to burial practices is widely documented in the Iberian prehistoric record and very often it has been traditionally interpreted as a ritual practice entailing the utilisation of local raw materials (iron oxides). Some research works, nevertheless, have also detected the use of red pigments which can only be interpreted as allochthonous. The red pigments spread over a single inhumation in a monumental Megalithic tomb surrounding Valencina de la Concepción Copper Age settlement was studied by means of X-ray diffraction, field emission scanning electron microscopy with energy dispersive X-ray spectroscopy, X-ray microfluorescence, micro-Raman and Fourier transform infrared spectroscopies. This approach allowed characterising the red pigments as cinnabar, mixed with tiny amounts of iron oxides. The presence of cinnabar, a product that was necessarily imported, in a context of an exceptional set of grave goods, suggests that the use of cinnabar was linked not only to ritual but also to practices related to the display of social status.
\end{abstract}


Keywords: cinnabar, Copper Age, Valencina de la Concepción, pigment characterisation, ritual, social inequality

\section{INTRODUCTION}

The symbolic, religious, or ritual dimension of extinct societies is one of the most difficult to grasp throughout the archaeological study of material remains. One of the generally accepted material markers for symbolic behaviour is the use of pigments with a non-utilitarian purpose, and especially their use in relation to burial practices. In Europe, the use of reddish pigments linked to symbolic practices appeared as early as in Middle Palaeolithic (Zilhão et al. 2010). In funerary contexts, the first known use of ochre dates to the first evidence for anatomically modern Homo sapiens in Eurasia (Hovers et al. 2003). In megalithic contexts of the Iberian Peninsula, numerous references to the use of red pigments related to human remains or covering orthostats and slabs of megaliths can be found in the scientific literature (e.g. Galán Saulnier 19841985, Cabrero García 1985, 1988, Zapatero 1989, Arteaga Matute and Cruz-Auñón 2001, Bueno Ramírez et al. 2005, Liesau et al. 2008, Lazarich González et al. 2009, Domínguez-Bella 2010, Briceño Briceño 2011). In the burials associated with the Chalcolithic settlement of Valencina de la Concepción (Sevilla, Spain), examples of both types of treatment have been reported: red pigment applied to the walls and ceiling of megaliths such as the Ontiveros (Carriazo y Arroquia 1962), and Montelirio dolmens (Hunt Ortiz and Hurtado Pérez 2010), or applied to the inhumations of the Matarrubilla dolmen (Collantes de Terán 1969) and tombs 2 and 3 of El Señorío de Guzmán (Arteaga Matute and Cruz-Auñón Briones 2001). The megalithic structure 10042-10049 of the PP4-Montelirio sector of the Valencina de la Concepción Copper Age settlement, also shows red pigments spread over the inhumations.

The red colour used in these Late Neolithic and Copper Age burial contexts has generally been referred to as "ochre" or "ruddle", implicitly assuming that its composition was based on ferric pigments. Iron is one of the most widespread elements in nature, being found quite easily in the form of oxides or oxyhydroxides, with natural reddish hues that can also be obtained by means of dehydration processes (Schwertmann and Cornell 1991). For this reason, iron based pigments should be 
usually considered a locally-obtained raw material. The natural region of El Aljarafe, a low level plateau on the west bank of the Guadalquivir River, on which the settlement of Valencina de la Concepción is situated, has abundant red or red-brown soils (Mudarra 1988). Due to the strong relationship between red colour and iron content (Torrent et al. 1983), these red soils would have been the source of local raw materials for these hypothetical ochres.

Many of the opinions on the composition of the red pigments in megalithic contexts have been formed without the help of analytical work. Most of them pre-date contemporary methods of scientific analysis, although the idea clearly persists in several recent publications (e.g. Arteaga Matute and Cruz-Auñón Briones 2001). When they have been characterised, many of the pigments previously considered to be iron oxides have proved to be cinnabar or a mix of cinnabar and iron oxides (Domínguez-Bella 2010, Lazarich González et al. 2010).

Cinnabar is a red coloured mineral composed of mercury sulphide $(\mathrm{HgS})$. As a pigment, cinnabar has been used to obtain the bright red colour known as vermilion, widely used by artists through history (Gettens et al. 1993). One of the oldest European references of the use of cinnabar dates back to the Neolithic site of Vinča, Serbia (Mioč et al. 2004, Gajić-Kvaščev et al. 2012). In the archaeological record of the Iberian Peninsula, the presence of cinnabar is detected as early as initial Neolithic at Cova de l'Or (Beniarrés, Valencia) (Domingo et al. 2012, García Borja et al. 2006, Roldán et al. 2008), at the Casa Montero (Madrid) Neolithic flint mine (Hunt-Ortiz et al. 2011), the Neolithic levels of Cueva de los Murciélagos, (Zuheros, Córdoba) (Gavilán and Rafael 1999, Martín-Fernández et al. 1999) or the dolmen of Alberite (Villamartín, Cádiz) (Ramos et al. 1997). Cinnabar is also the main ore of mercury and its extraction is documented at least since Roman times (Agnoli et al. 2007, Mazzocchin et al. 2008, Spangenberg et al. 2010). Cinnabar origin, linked to magmatic and hydrothermal contexts, as impregnations and veins within rocks (Klein and Hurlburt 1998), makes it relatively scarce in nature. In most cases, these characteristic conditions the interpretation of the presence of cinnabar as a marker for long distance goods interchange relationships.

The aim of this paper is to elucidate the composition of the pigments used in the context of the burial practices of the 10042-10049 megalithic tomb of PP4-Montelirio, one of 
the most outstanding graves so far recorded at the Chalcolithic site of Valencina de la Concepción (Sevilla, Spain).

\section{MATERIALS AND METHODS}

\subsection{The PP4-Montelirio 10042-10049 megalithic structure}

Situated in the lower Guadalquivir valley, in the highlands of the northern Aljarafe plateau in the province of Seville, Valencina de la Concepción is one of the most important settlements of the $3^{\text {rd }}$ millennium BCE in the south of the Iberian Peninsula (Figure 1). The importance of this settlement derives from its extent (circa $400 \mathrm{Ha}$ ), the exceptional range of megalithic structures present and from the density and diversity of the contexts recorded (Vargas Jiménez 2003). The last of these has recently been reinforced by geophysical surveys of unexcavated parts of the site (Wheatley et al. 2012) which confirm the exceptional density of archaeological contexts and structures that have previously been documented in the excavated areas (Vargas Jiménez 2004). Furthermore, the approximately 120 excavations performed since the discovery in 1868 of the La Pastora megalithic monument possibly make Valencina de la Concepción the most intensely excavated prehistoric site in Spain.

Paradoxically, in spite of its high scientific value and the large number of excavations undertaken, the data available for interpretation of the site are not abundant and have major limitations. Recently, a few papers have dealt with several of the interpretative problems of Valencina in a global perspective (Nocete Calvo et al. 2007, Costa Caramé et al. 2010, Wheatley et al. 2012, García Sanjuán and Murillo-Barroso in press). Until recent years, almost all the field work was undertaken in small areas located in different parts of the site, showing a very fragmented vision of the settlement.

However, the archaeological works carried out at PP4-Montelirio during the years 2007 and 2008 represent the biggest coherent area ever excavated at the site (around 18.87 Ha) allowing, for the first time, the opportunity to approach global interpretative questions about the site that require a wider spatial perspective. In this sector of Valencina, 134 Chalcolithic structures - 61 funerary and 73 non-funerary- were found, and at least another 10 structures were identified as Chalcolithic although not excavated. 
The PP4-Montelirio sector offers, for the first time, the possibility of analysing the variability of the burial structures built and utilised by the prehistoric inhabitants of Valencina.

Among the funerary structures excavated at PP4-Montelirio, structure 10042-10049 (Figure 2) is outstanding. It is located in sector $\mathrm{C}$ and occupies a central, prominent position, surrounded by several funerary and non-funerary structures that are located at a minimum distance of $9.25 \mathrm{~m}$ defining an apparently empty surrounding area.

Structure 10042-10049 is the remains of a two-chambered megalithic construction. This consisted of an access passage made of 57 slate slabs (29 on the north side, 28 on the south), and a further 13 slabs inside. With a maximum length of $13 \mathrm{~m}$ and $0.7 \mathrm{~m}$ maximum width, the passage is subdivided by small slate lintels into three sections of $6.8 \mathrm{~m}, 2.4 \mathrm{~m}$ and $2.8 \mathrm{~m}$ respectively. At the end of the last of these is the first chamber which has a maximum diameter of $2.57 \mathrm{~m}$, and in which only five slate slabs were found in their original positions delimiting the chamber, and another 3 slabs over it. This first chamber had been disturbed by the trenches of an archaeological survey in 1998. Beyond the first chamber, a second corridor of $2.52 \mathrm{~m}$ by $0.51 \mathrm{~m}$ and constituted of 15 slate slabs ( 7 on the north side and 8 on the south) separates the first and the second burial chambers. The second chamber, found in a better state of preservation than the first, has a maximum diameter of $2.1 \mathrm{~m}$ and is formed of 23 slabs. The excavation allowed the detection of two independent deposits separated by a "pavement" of 22 slate slabs, interpreted as either a seal for the lower depositional level or as the product of a collapse of slabs. Above the upper depositional level, 12 more slate slabs were found.

In the space between the access passage and the first chamber, skeletal remains of four individuals were identified as well as more than 2000 beads and red pigment, four fragments of a fired clay figurine, more than 800 potsherds (some of them intrusive wheel-thrown pottery), fragments of 12 arrowheads, 3 blade fragments, a quantity of chipping debris, ivory objects (very fragmented, and some of them decorated), two specimens of marine shell, several fragments of terrestrial snails, antlers and several intrusive iron fragments. 
The lower depositional level of the second chamber (SU 664) contained one individual articulated inhumation (Figure 3), lying in the foetal position, with red pigment spread on the right lateral decubitus. Associated with this skeleton was an undecorated elephant tusk beside the head, one borde almendrado plate (a characteristic Copper Age vessel form) also with red pigment, a set of 23 flint blades, one flint halberd with an amber pommel, numerous ivory objects (most of them decorated and very fragmented) and a copper awl.

In the upper depositional level of the second chamber (SU 535) (Figure 4) the finds comprised five ceramic pots (two complete plates -one with red pigment- and two half plates, one of them also with red stains), one extraordinary rock crystal halberd, a set of 38 flint blades and 16 fragments, one flint arrow point, numerous ivory objects (most of them decorated and quite fragmented, between them a palette and the terminal extreme of a tusk, both decorated), 90 beads, and an ostrich egg.

To summarise, this burial structure contains a remarkably rich assemblage of grave goods including more than 50 objects in the first chamber and the passage, more than 30 objects in the first depositional level and more than 70 in the second level of the second chamber. This is the only structure in the PP4-Montelirio sector in which the use of red pigment has been detected. The rich set of grave goods recorded in the lower depositional level of the second chamber (SU 664) may be safely attributed to a single individual, which underlines the high social position of this person (see further discussion below).

\subsection{Samples}

Twelve samples were taken from different elements present in the structure 1004210049 in order to characterise the red pigment covering human bones, grave goods and even the floor surface. Pigment samples were scraped with a sterile scalpel and stored in Eppendorf inert tubes. A tiny part of the supporting material was also collected for comparison purposes. Table 1 describes the different samples analysed in this work.

\subsection{Analytical techniques}

\subsection{1. $X$-ray diffraction (XRD)}


Crystalline compounds present in the analysed samples were characterised by X-ray diffraction employing a Siemens Kristalloflex D-5000 diffractometer, employing $\mathrm{Cu} \mathrm{K} \alpha$ $(40 \mathrm{kV}, 30 \mathrm{~mA})$ radiation, graphite monocromator and scintillation detector. The measurements were carried out with powder samples in the range $3^{\circ}<2 \theta<65^{\circ}$ with a step of $0.05^{\circ}$ and 2 seconds per step. For the identification of the present phases, the database of the software DIFFRAC plus EVA (Bruker, Germany) was employed. It is necessary to underline that the crystalline phases can be identified by conventional XRD only if the amount in the sample is enough to give a good signal-to-noise ratio (Duran et al. 2010). Consequently, minority compounds can be masked by the background noise.

In order to obtain a complete characterisation of the natural state of the soil clays of the site, earth surrounding structure 10042-10049 and the content of a complete hemispherical bowl of the same SU were sampled and studied by XRD before and after the extraction of carbonates (see Supplementary Information).

\subsubsection{Scanning electron microscopy and elemental chemical analysis (SEM/FEG-EDS)}

SEM micrographs were obtained with a Hitachi S-4800 microscope. Semiquantitative elemental chemical analysis of samples was obtained with a Bruker XFlash Detector 4010 Energy dispersive X-ray spectrometer using a voltage of $15-20 \mathrm{keV}$.

\subsubsection{X-ray microfluorescence $(\mu E D X R F)$}

The composition of the samples was also characterised by energy dispersive X-ray fluorescence ( $\mu$-EDXRF), performed on three spots for each sample. An external probe X-ray fluorescence spectra were obtained on small samples with an ArtTAX spectrometer of Intax $\mathrm{GmbH}$, with a molybdenum (Mo) anode, Xflash detector refrigerated by the Peltier effect (Sidrift), with a mobile arm and a spatial resolution of $70 \mu \mathrm{m}$.

\subsubsection{Micro Raman spectroscopy}

$\mu$-Raman spectra of the samples were acquired using a LabRAM Horiba Jobin Yvon spectrometer equipped with a Full area CCD detector, using 785nm CLDS point mode diode laser for confocal Raman measurements. The wavelength range of recording was of $100-1800 \mathrm{~cm}^{-1}$ using a $20 \mathrm{X}, 50 \mathrm{X}$ and $100 \mathrm{X}$ magnification objectives. Raman spectra 
were collected for 3-6 min with a spectral resolution of $2 \mathrm{~cm}^{-1}$. The laser power was kept as low as possible $(0,5 \mathrm{~mW})$ to avoid sample degradation.

\subsubsection{Fourier-transform infrared spectroscopy (FTIR)}

Samples were separately examined by a Fourier transform infrared (FT-IR) spectrometer equipped with a MCT detector (JASCO FT-IR 6200). All the FT-IR spectra were obtained at a $4 \mathrm{~cm}^{-1}$ resolution and 100 scans. The IR absorption measurements were done using the $\mathrm{KBr}$ pellet technique.

\section{RESULTS}

\subsection{X-ray diffraction}

The study by XRD of samples O1-H1, ML05 (ivories), O2-H2 (bone), and O1-C1 (pottery) allowed the detection of cinnabar $(\mathrm{HgS})$ as the main crystalline compound of the red stains. Also, different compounds related to the medium were identified: hydroxylapatite $\left(\mathrm{Ca}_{10}\left[\mathrm{PO}_{4}\right]_{6}[\mathrm{OH}]_{2}\right)$ reflecting the composition of the ivory of O1-H1 and ML05, and the bone of $\mathrm{O} 2-\mathrm{H} 2$; and calcite $\left(\mathrm{CaCO}_{3}\right)$ and quartz $\left(\mathrm{SiO}_{2}\right)$, components of the ceramic paste of O1-C1 (Figures 5-6).

XRD analyses conducted on clays from a globular bowl of the same stratigraphic unit, and from the soil out of the tomb also showed quartz and calcite as the main crystalline phases (see Supplementary Information, Figures S1-S6). After the extraction of carbonates, the clay minerals detected were illite $\left(\mathrm{K}, \mathrm{H}_{3} \mathrm{O}\right)(\mathrm{Al}, \mathrm{Mg}, \mathrm{Fe})_{2}(\mathrm{Si}, \mathrm{Al})_{4} \mathrm{O}_{10}\left[(\mathrm{OH})_{2},\left(\mathrm{H}_{2} \mathrm{O}\right)\right]$, and kaolinite $\mathrm{Al}_{2} \mathrm{Si}_{2} \mathrm{O}_{5}(\mathrm{OH})_{4}$, which lead us to consider that the titanium content is better explained in relation to the iron oxides. Other detected elements, as $\mathrm{Al}$ or $\mathrm{K}$ can also be related to the clay minerals illite and kaolinite, and the presence of $\mathrm{Zn}$ should be related to the iron oxides.

\subsection{Scanning electron microscopy and elemental chemical analysis (SEM/FEG- EDS)}

EDS analyses of sample O1-C1 allowed the detection of other elements, as A1, related jointly with $\mathrm{Si}, \mathrm{Ca}$ and $\mathrm{C}$ with the clay matrix of the ceramic paste, and also $\mathrm{Fe}$, 
interpreted as a minority presence of ferric oxides or oxyhydroxides. (Figure 7). Other EDS spectra of the same sample in other regions did not detect the presence of iron, in concordance with this last appreciation. The presence of Mn was also detected in O1$\mathrm{C} 1$, attributed to the clay matrix or the ferric oxides to which is usually related.

SEM imaging allowed identifying some particles dispersed onto the pottery surface (Figure 7a). SEM observation of these particles reflects different features. In the case of the morphology found in Figure $7 \mathrm{~b}$, the chemical analyses show the presence of mercury and sulphur associated to cinnabar particles, and in the case of particles shown in Figure $7 \mathrm{c}$ the chemical analysis indicate that these particles are associated to a mixture of cinnabar and iron.

The EDS spectrum obtained for sample $\mathrm{O} 1-\mathrm{H} 2$ showed the presence of $\mathrm{P}$ and $\mathrm{Ca}$, related to the hydroxylapatite of the ivory composition and also $\mathrm{Si}$ and $\mathrm{Al}$, originated from the clay sediments. The elements $\mathrm{S}$ and $\mathrm{Hg}$ were also detected (Figure 8). This ivory fragment also showed a high degree of modern microbial colonisation. The growth of microorganisms (Figure 8a) provides fresh organic matter, and this data is interesting in order to evaluate the accuracy of radiocarbon dating due to the rejuvenating effects of this new carbon contribution (Wohlfarth et al. 1998).

Electron micrographs showed that cinnabar particles presented very small sizes, occasionally nanometric, and generally of some micrometers (Figure 8b), that would reflect a prolonged grounding using hard stones. One of these kinds of possible tools, also related to a burial context but in another archaeological site, is a red-stained spilite tool described by Polvorinos del Río et al (2001), used in this last case to ground hematite.

\subsection{X-ray microfluorescence}

The study of the samples throughout $\mu$ EDXRF allowed the detection in ten samples (Table 2) of $\mathrm{Hg}$ and $\mathrm{S}$, and also Fe in all them, showing that the pigment is in fact a mix of cinnabar and ferric oxides (Figure 9). A low signal corresponding to Ti was also detected in these samples (Table 2), attributed to rutile $\left(\mathrm{TiO}_{2}\right)$, that could be related both with the ferric oxides or the clay sediments (Gil et al. 2007). SEM micrographs also 
allowed finding some rutile crystals on the surface of sample O2-H2 (Figure 10). The presence of Mn was detected in seven samples, also attributed to the clay matrix or the ferric oxides to which is usually related. Table 2 summarizes the elemental composition obtained for each sample.

\subsection{Raman and FTIR spectroscopies}

The Raman spectra obtained from the surface of the red pigment onto ivory and bone fragments exhibit bands at 253,283 and $343 \mathrm{~cm}^{-1}$ assigned to a cinnabar pigment (Figure 11b). Raman spectrum of ivory is dominated by the internal $\mathrm{PO}_{4}{ }^{3-}$ modes. The vibrational frequencies of the free $\mathrm{PO}_{4}{ }^{3-}$ were found at 402, 420, 643 and $872 \mathrm{~cm}^{-1}$. The cinnabar pigment was present in all the samples studied by Raman spectroscopy (Figures 11b,d,f).

FTIR spectra allowed to detect the main composition of the ceramic paste in sample O1-C2, with bands associated with the clay minerals at $324 \mathrm{~cm}^{-1}, \mathrm{Si}-\mathrm{O}$, and $\mathrm{Al}-\mathrm{O}$ deformation band appearing at about $473 \mathrm{~cm}^{-1}$. The strong band of hematite expected at $304 \mathrm{~cm}^{-1}$ is unfortunately overlapped by the very strong calcite bands. Nevertheless, bands observed at $536 \mathrm{~cm}^{-1}$ could indicate the presence of hematite, at $1428 \mathrm{~cm}^{-1}$ carbonate ion associated to calcite, and the doublet at about 751 and $798 \mathrm{~cm}^{-1}$ indicates that some quartz is present (Figure 12a). The main $\mathrm{Si}-\mathrm{O}$ stretching band is observed at $1030 \mathrm{~cm}^{-1}$ indicating that the ceramic paste was fired below $600^{\circ} \mathrm{C}$ because this bands shifts and slight splits over after firing at $700^{\circ} \mathrm{C}$ (Shoval and Beck 2005).

Figure $12 \mathrm{~b}$ shows the FTIR spectrum of the bone and ivory materials. The bending vibration bands of phosphate associated to hydroxylapatite are clearly identified, the

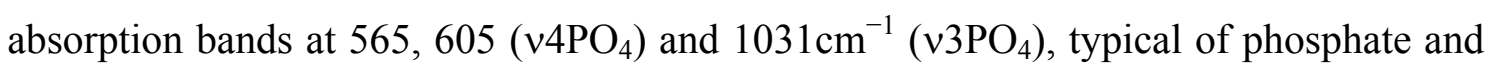
$1428 \mathrm{~cm}^{-1}\left(v 3 \mathrm{CO}_{3}\right)$, and $871 \mathrm{~cm}^{-1}\left(v 2 \mathrm{CO}_{3}\right)$ typical of carbonate in apatite (Lebon et al. 2010, Piga et al. 2011). The amide I was observed at $1642 \mathrm{~cm}^{-1}$, the amide II band was observed near $1540 \mathrm{~cm}^{-1}$. The absorbance intensity of the amide I and amide II, of the bone and ivory samples was low, maybe due to the deterioration of collagen (Chadefaux et al. 2009). The bands associated with the iron oxide pigments are present at $536 \mathrm{~cm}^{-1}$ and $468 \mathrm{~cm}^{-1}$ on both samples. These iron pigments are present in very low concentrations and have a low crystallization degree. 


\section{DISCUSSION}

The application of various characterisation techniques reveals that the red pigment found covering both the inhumation and grave goods of structure 10042-10049 at PP4Montelirio has as chromophore groups a mix of cinnabar and iron oxides or oxyhydroxides.

In the literature, red pigments recorded in other Copper Age burial contexts have been generically described as 'ochre' or 'ruddle', and in some cases as 'iron oxides' or even 'hematite' (Carriazo y Arroquia 1962, Collantes de Terán 1969, Zapatero 1989, Arteaga Matute and Cruz-Auñón Briones 2001). However, whenever analytical characterisation has been carried out, cinnabar has frequently been identified (Gavilán 1987, Martin-Gil et al. 1995, Ramos et al. 1997, Gavilán and Vera 2004, Liesau et al. 2008, DomínguezBella 2010, Dias et al. 2011). In such cases, cinnabar may appear either in a pure state or mixed with certain amounts of ferric oxides or oxyhydroxides, as documented at structure 10042-10049 of PP4-Montelirio, at the Montelirio 'dolmen' itself (Hunt Ortiz and Hurtado Pérez 2010) and at the hipogea of Paraje de Monte Bajo (Cádiz) (Lazarich González et al. 2010).

The magmatic and hydrothermal origin of cinnabar ores suggests that the sources of the pigment used in Montelirio may be many kilometres away from the site. Recent research based on Thermal Ionization Mass Spectrometry (Hunt Ortiz and Hurtado Pérez 2010, Hunt Ortiz et al. 2011) suggests that these outcrops are located in the mining district of Almadén (Ciudad Real, in the Spanish central plateau), thus ruling out nearer alternative sources such as Usagre (Badajoz, Spain) and Timar (Granada, Spain), which had been previously discussed. Although the excavators of Paraje de Monte Bajo mention cinnabar outcrops in Almadén de la Plata and Guadalcanal, in the province of Seville (Lazarich González et al. 2010), this seems to be an error caused by the homonymy of the toponyms (Almadén, Ciudad Real, vs. Almadén de la Plata, Seville). Published data of the Iberian Pyrite Belt metalogenic area do not mention the presence of cinnabar (Tornos Arroyo 2008). Moreover, the mercury employed for the amalgamation of the silver in the mines of Guadalcanal (Seville) in the $16^{\text {th }}$ century CE was carried from Almadén (Ciudad Real) following the route marked by the Camino 
Real del Azogue (Sánchez Gómez et al. 1997). This fact makes the existence of cinnabar outcrops at Guadalcanal or Almadén de la Plata quite improbable.

Cinnabar, therefore, can be considered a scarce and exotic product, which makes it a commodity with a dual symbolic and social value whose use or accumulation may be related to special ritual practices but also to the prestige or social status of its owner. At the dolmen of La Velilla (Palencia, Spain), cinnabar of great purity, apparently washed and finely ground in order to obtain a purer colour, was found in great amounts, estimated by the researchers to reach hundreds of kilograms (Martin-Gil et al. 1995). At PP4-Montelirio structure 10042-10049, cinnabar particles show a nanometric size that implies a meticulous grinding treatment with hard stones that would have produced a bright red colour. The pigment occurs mixed with ferric oxides and in relatively small quantities, spread over the corpse and grave goods. Similarly, the cinnabar employed in painting the large slate slabs of the Montelirio megalith was also found to be mixed with iron oxides (Hunt Ortiz and Hurtado Pérez 2010). There seems to be little doubt that the utilisation of cinnabar had a clear ritual and symbolic dimension for the Copper Age settlers of Valencina. Whatever the specificities of this dimension were, it seems also clear that it was generally related to the world of the dead: at Valencina, red pigments have not been found inside domestic structures - i.e. in the world of the living. In addition, the rareness of this mineral and, presumably, its high "value" (Ramos et al. 1997) must have connected the use of the pigment to the funerary display of wealth and/or power of individuals of high social status. The mixing of cinnabar with ferric oxides or oxyhydroxydes could reflect the need to "adulterating" the cinnabar with other lesser-quality red pigments that were more easily available locally in an attempt to amplify the reach of such displays. The use of cinnabar may thus reflect social differentiation - derived from the high value of the product because of its rareness, scarcity and physical properties.

Exotic commodities are clear indicators of distribution networks that may, or not, imply the presence of trade. In a review work on the issue, Adams (1974) focused the attention to the fact that socio-political complexity does not constitute a precondition for trade. On the other hand, Oka and Kusimba (2008: 367) concluded that "trade and trading behaviors in the past were parallel processes accompanying social evolution". In a general sense, it is patent that exchange is linked to the very first origins of humankind, 
including not only raw materials but probably daily life elements. It is also clear that the exchange of prestige goods can be linked to the accumulation of wealth inside social "elites" in some archaeological contexts, and this can be the case of Valencina de la Concepción. Renfrew (1969: 154) wrote in his seminal article about two kinds of trade, “... of material commodities whose natural distribution is limited ... and of products which, through superior know-how or other economic factors, are most efficiently produced in a limited area". The first of these kinds seems the most suitable to the case of Valencina, in which cinnabar (but also ivory, amber, ostrich egg, or "rare" stones [Costa Caramé et al. 2011]) appear in a short number of all the documented funerary structures, the scarce distribution of these archaeological evidences pointing to the appropriation of exotic commodities by a little part of the inhabitants of the site.

Some authors (e.g. Galán Saulnier 1984-1985) have speculated about possible secondary deposition of pigmented bones or the use of cinnabar as a dye for the clothing of corpses at the El Redondil megalith (Zamora, Spain). Although this utilitarian use is possible, the use of the pigment at PP4-Montelirio structure 10042-10049, spread both over the corpse and the different grave goods, suggests a ceremonial (ritual) use of the cinnabar after the deposition of the body and the grave goods. It is feasible that the bright red colour of the cinnabar is in itself proof of the integrity of the grave because exposure to light provokes darkening of the pigment (Keune and Boon 2005). Moreover, no degradation products of cinnabar, as sulphides, have been detected in the structure 10042-10049 samples.

Blasco Bosqued and Ríos Mendoza (2010) have drawn attention to the repeated association of ivory and gold elements in the presence of cinnabar in burial contexts. In their work, the authors discuss this association as a possible indicator of stipulated and coordinated exchange circuits. Both in the cases of PP4-Montelirio structure 1004210049 and Matarrubilla this association of elements occurs, enriched in the latter case with the presence of elements of "calaite" (a synonym for turquoise or, in general, green stones) and, in the former, with the presence of amber, both of unquestionable allochthonous origin. Structure 10042-10049 has yielded what possibly amounts to the largest single collection of ivory objects ever found in an Iberian Copper Age burial. 
Other authors, however, point to the qualities of cinnabar for the preservation of corpses (which stem from the mercury compounds) as a possible cause for its use in burial practices (Delibes de Castro 2000, Blas Cortina 2003, Martín-Gil et al. 2005), and which might explain the purity of the cinnabar at the La Velilla grave. The presence of ferric oxides mixed with cinnabar in multiple findings, however, suggests that preservative properties were of secondary interest if they were known at all to the members of the societies that used them in burial contexts.

We have no way to assess with certainty assertions about the symbolic meaning of red pigments involving conceptions of the afterlife - as for example in a "vivifying blood bath" (Rubio de Miguel 1989:28), but we can appreciate that some differences in treatment between corpses do exist, which may relate to differences in wealth and/or social status between persons (Bellido Blanco and Gómez Blanco 1996). In this sense, the use of cinnabar dust may be seen as another signifier of social differentiation, complementary to its possible ritual and utilitarian uses. In the case of the individual buried in PP4-Montelirio's structure 10042-10049, this is underlined by (i) the fact that this individual was accompanied by a set of grave goods that included an unusually high number of objects, some of which are hard not to interpret as 'prestige objects' (even if we exclude the set of objects found in the upper stratigraphic level of this chamber, above this inhumation, for which there is no hard evidence of contemporaneity). This is the case particularly for the unworked elephant tusk placed beside the man's head and the flint dagger that was by his side. The analytical study of the amber pommel associated with this dagger has shown it to be from Sicily (Murillo-Barroso and García Sanjuán in press, Murillo-Barroso and Martinon-Torres 2012); (ii) the use of the pigment itself: in a context of 61 funerary structures in the same sector this is the only tomb in which cinnabar was detected; (iii) the fact that red pigments are spread only over a little portion of the total corpses documented at Valencina, indicating differences in the treatment of some individuals respect to the others; and (iv) the proper complexity of the plan of the tomb, which is only comparable at the site with other two tombs (one of them with an important amount of cinnabar used to paint the orthostats and cover the corpses and grave goods). The use of cinnabar at this individual's burial must, therefore, have served at least in part to underline the high social rank of a person who was also provided with a series of valuable and exotic objects. 


\section{CONCLUSIONS}

The use of XRD and Raman spectroscopy allowed us to characterise the pigment spread over the inhumation and grave goods of a megalithic structure as cinnabar, in some cases mixed with tiny amounts of iron oxides (not detected by XRD but appearing Fe in EDS and $\mu$ EDXRF spectra of different samples; also traces of iron oxides were detected using FTIR). The iron pigments are present in very low concentrations and have a low crystallization degree. In addition, these pigments were mixed with cinnabar, conditioning the weak diffraction intensity of the iron oxides.

Cinnabar is a product which is scarce in nature and nonexistent near Valencina. Moreover, its preparation as a finely ground powder requires a great investment of time. In conjunction with the rest of the valuable artefacts found with the corpse, the presence of cinnabar in this tomb leads us to conclude that cinnabar is not only a ritual element (suggested by the non-existence of a counterpart of this pigment in elements of daily life at this specific site), but that its use is related to the display of power, status or wealth: in other words, that it is an indicator of social status. The presence of iron oxides, a cheap and locally available pigment, mixed with the cinnabar, is perhaps best explained as a means for magnifying this display using locally available materials.

\section{ACKNOWLEDGEMENTS}

L.K Herrera thanks CSIC for JAE-DOC contract. This is a Consolider TCP CSD200700058 paper.

\section{REFERENCES}

Adams, R.M., 1974. Anthropological perspectives on ancient trade. Curr. Anthropol. $15,239-258$.

Agnoli, F., Calliari, I., Mazzocchin, G.A., 2007. Use of different spectroscopic techniques in the analysis of Roman age wall paintings. Ann. Chim. 97, 1-7.

Arteaga Matute, O., Cruz-Auñón Briones, R., 2001. Las nuevas sepulturas prehistóricas (tholoi) y los enterramientos bajo túmulos (tartesios) de Castilleja de Guzmán 
(Sevilla). Excavación de urgencia de 1996. Anuario Arqueológico de Andalucía 1996, III, 640-651.

Bellido Blanco, A., Gómez Blanco, J.L.A., 1996. Megalitismo y rituales funerarios. Complutum Extra 6(1), 141-152.

Blas Cortina, M.A. 2003. Estelas con armas: arte rupestre y paleometalurgia en el norte de la Península Ibérica, in: Balbín, R., Bueno, P. (Eds.), El arte prehistórico desde los inicios del siglo XXI. Primer Symposium Internacional de Arte Prehistórico de Ribadesella, Asociación Cultural Amigos de Ribadesella, Ribadesella, pp. 391418.

Blasco Bosqued, C., Ríos Mendoza, P., 2010. La función del metal entre los grupos campaniformes. Oro versus cobre. El ejemplo de la Región de Madrid. Trabajos Prehist. 67(2), 359-372.

Briceño Briceño, E.M. 2011. La versatilidad de los colorantes minerales rojos en la Prehistoria Reciente: Andalucía occidental, in: Abellán Pérez, J., Lazarich González, M., Castañeda Fernández, V. (Eds.), Homenaje al Profesor Antonio Caro Bellido. Tomo I. Prehistoria y Protohistoria de Andalucía y Levante. Universidad de Cádiz, Cádiz, pp.39-60.

Bueno Ramírez, P., Barroso Bermejo, R., de Balbín Behrmann, R., 2005. Ritual campaniforme, ritual colectivo: la necrópolis de cuevas artificiales del Valle de las Higueras, Huecas, Toledo. Trabajos Prehist. 62(2), 67-90.

Cabrero García, R., 1985. La necrópolis de cuevas artificiales de Juan Corrales (Gilena) y Cerro del Ojo (Pedrera) en la provincia de Sevilla. Prehistoria 3, 1-26.

Cabrero García, R., 1988. El megalitismo en la provincia de Huelva, II: estudio aproximativo del ritual sepulcral y de la cronología de los monumentos tomando como base los restos encontrados en su interior. Huelva en su Historia 2, 57-118.

Carriazo y Arroquia, J.M., 1962. El Dolmen de Ontiveros, in: Homenaje al profesor Cayetano de Mergelina. Universidad de Murcia, Murcia, pp. 209-229.

Chadefaux, C., Le Hô, A-S., Bellot-Gurlet, L., Reiche, I., 2009. Micro-ATR-FTIR studies combined with the curve-fitting of the amide I and II bands of type I collagen in archaeological bone materials. e-Preserv. Sci. 6, 129-137.

Collantes de Terán, F., 1969. El dolmen de Matarrubilla, in: Tartessos y sus problemas: V Symposium internacional de Prehistoria Peninsular. Jerez de la Frontera, Septiembre 1968. Universidad de Barcelona, Barcelona, pp. 47-61. 
Costa Caramé, M.E., Díaz-Zorita Bonilla, M., García Sanjuán, L., Wheatley, D.W., 2010. The Copper Age settlement of Valencina de la Concepción (Seville, Spain): Demography, metallurgy and spatial organization. Trabajos Prehist. 67(1), 85117.

Costa Caramé, M.E., García Sanjuán, L., Murillo-Barroso, M., Parrilla Giráldez, R., Wheatley, D.W., 2011. Artefactos elaborados en rocas raras en los contextos funerarios del IV-II milenios cal ANE en el sur de España: una revisión, in: García Sanjuán, L., Scarre, C., Wheatley, D.W., (Eds.), Exploring Time and Matter in Prehistoric Monuments: Absolute Chronology and Rare Rocks in European Megaliths. Junta de Andalucía, Antequera, pp. 253-293.

Delibes de Castro, G., 2000. Cinabrio, huesos pintados en rojo y tumbas de ocre: ¿Prácticas de embalsamamiento en la Prehistoria?, in: Olcina, M., Soler, J. (Eds.), Scripta in Honorem Enrique A. Llobregat Conesa. Instituto Alicantino Juan GilAlbert, Alicante, vol. 1, pp. 223-236.

Dias, L., Oliveira, J., Rocha, L., Rosado, L., Dias, C., Ferreira, T., Candeias, A., Mirao, J., 2011. Sobre a presença de Cinábrio em rituais funerários no Megalitismo do Alentejo, Portugal, in: IX Congresso Ibérico de Arqueometria, Lisboa, 26 a 28 de Outubro de 2011. Livro de resumos. Lisboa, p. 93.

Domínguez-Bella, S., 2010. Aplicaciones de las técnicas experimentales y la mineralogía a la arqueometría. Los pigmentos de cinabrio del dolmen de Alberite I, Villamartín (Cádiz), in: Domínguez-Bella, S., Ramos Muñoz, J., Gutiérrez López, J.M., Pérez Rodríguez, M., (Eds.), Minerales y rocas en las sociedades de la prehistoria. Universidad de Cádiz, Cádiz, pp. 235-244.

Domingo, I., García-Borja, P, Roldán, C., 2012. Identification, processing and use of red pigments in the Valencian early Neolithic (Spain). Archaeometry (in press), doi: 10.1111/j.1475-4754.2011.00650.x.

Duran, A., Jiménez de Haro, M.C., Pérez-Rodríguez, J.L., Franquelo, M.L., Herrera, L.K., Justo, A., 2010. Determination of pigments and binders in Pompeian wall paintings using Synchrotron Radiation - High Resolution X-Ray Powder Diffraction and conventional Spectroscopy - Chromatography. Archaeometry 52(2), 286-307.

Gajić-Kvaščev, M., Stojanović, M.M., Šmit, Ž., Kantarelou, V., Karydas, A.G., Šljivar, D., Milovanović, D., Andrić, V. 2012. New evidence for the use of cinnabar as a 
colouring pigment in the Vinča culture. J. Archaeol. Sci., doi: 10.1016/j.jas.2011.11.023.

Galán Saulnier, C., 1984-1985. Los túmulos colectivos no megalíticos de la meseta. Cuadernos de Prehistoria y Arqueología de la Universidad Autónoma de Madrid 11-12, 57-68.

García Borja, P., domingo, I., Roldán, C., 2008. Nuevos datos sobre el uso de materia colorante durante el neolítico antiguo en las comarcas centrales valencianas. Saguntum (PLAV) 38, 157-162.

García Sanjuán, L., Murillo-Barroso, M., in press. Social Complexity in Copper Age Southern Iberia (c. 3200-2200 cal BC): Reviewing the "state" hypothesis at Valencina de la Concepción (Seville, Spain), in: Cruz Berrocal, M., García Sanjuán, L., Gilman, A., (Eds.), The Prehistory of Iberia: Debating Early Social Stratification and the State. Routledge, New York.

Gavilán, B., 1987. Excavación Arqueológica de Urgencia en el Dolmen de Las Casas de Don Pedro (Belmez, Córdoba), in: Anuario arqueológico de Andalucía 1986. Junta de Andalucía, Sevilla, vol. 3, pp. 118-120.

Gavilán, B., Rafael, J.J., 1999. Análisis de la industria ornamental de la Cueva de los Murciélagos de Zuheros (Córdoba), in: Bernabeu, J., Orozco, T. (Eds.), II Congreso de Neolítico de la Península Ibérica. Saguntum (PLAV), Extra 2, 157 162.

Gavilán, B., Vera, J.C., 2004. Excavación Arqueológica (I.A.U. de apoyo a la restauración) en el Dolmen de Las Casas de Don Pedro (Belmez, Córdoba). Anuario arqueológico de Andalucía 2001. Junta de Andalucía, Sevilla, vol. 3, pp. 291-296.

Gettens, R.J., Feller, R.L., Chase, W.T., 1993. Vermilion and cinnabar, in: Roy, A., (Ed.), Artist's pigments: A Handbook of their History and Characteristics, vol. 2. Oxford University Press, Oxford, pp. 159-182.

Gil, M., Carvalho, M.L., Seruya, A., Candeias, A.E., Mirão, J., Queralt, I., 2007. Yellow and red ochre pigments from southern Portugal: Elemental composition and characterization by WDXRF and XRD. Nucl. Instrum. Methods Phys. Res. A $580,728-731$

Hovers, E., Ilani, S., Bar-Yosef, O., Vandermeersch, B., 2003. An early case of color symbolism. Ochre use by modern humans in Qafzeh Cave. Curr. Anthropol. 44, 491-522. 
Hunt Ortiz, M.A., Hurtado Pérez, V.M., 2010. Pigmentos de sulfuro de mercurio cinabrio- en contextos funerarios de época calcolítica en el sur de la Península Ibérica: investigaciones sobre el uso, depósitos minerales explotados y redes de distribución a través de la caracterización composicional e isotópica, in: Sáiz Carrasco, M.E., López Romero, R., Cano Díaz-Tendero, M.A., Calvo García, J.C., (Eds.), VIII Congreso Ibérico de Arqueometría. Actas. Seminario de Arqueología y Etnología Turolense, Teruel, pp. 123-131.

Hunt Ortiz, M.A., Consuegra-Rodríguez, S., Díaz del Río-Español, P., Hurtado-Pérez, V., Montero-Ruiz, I., 2011. Neolithic and Chalcolithic - VI to III millenia BC use of cinnabar $(\mathrm{HgS})$ in the Iberian Peninsula: Analytical identification and lead isotope data for an early mineral exploitation of the Almadén (Ciudad Real, Spain) mining district, in: Ortiz, J.E., Puche, O., Rábano, I., Mazadiego, L.F., (Eds.), "History of research on mineral resources". Cuadernos del Museo Geominero 13, 3-13. IGME, Madrid.

Keune, K., Boon, J.J., 2005. Analytical imaging studies clarifying the process of the darkening of Vermilion in paintings. Anal. Chem. 77, 4742-4750.

Klein, C., Hurlburt, C.S., 1998. Manual of Mineralogy (after James D. Dana). 21st ed., revised. Wiley, New York.

Lazarich González, M., Fernández de la Gala, J.V., Jenkins, V., Peralta, P., Briceño, E., Ramos, A., Richarte, M.J., Carreras, A.M., Núñez, M., Versaci, M., Stratton, S., Sánchez, M., Grillé, J.M., 2009. Paraje de Monte Bajo (Alcalá de los Gazules). Una nueva necrópolis de cuevas artificiales en el Sur de la provincia de Cádiz. Almoraima 39, 67-83.

Lazarich González, M., Briceño Briceño, E.M., Feliú Ortega, M.J., 2010. El empleo de ocres en las sepulturas prehistóricas de la Baja Andalucía: la necrópolis de Paraje de Monte Bajo, in: Pérez Macías, J.A., Romero Bomba, E., (Eds.), Actas del IV Encuentro de Arqueología del Suroeste Peninsular (Aracena, Noviembre de 2008). Universidad de Huelva, Huelva, com. 18.

Lebon, M., Reiche, I., Bahain, J.J., Chadefaux, C., Moigne, A.M., Fröhlich, F., Sémah, F., Schwarcz, H.P., Falguères C. 2010. New parameters for the characterization of diagenetic alterations and heat-induced changes of fossil bone mineral using Fourier Transform Infrared Sspectrometry. J. Archaeol. Sci. 37, $2265-2276$. 
Liesau, C., Blasco, C., Ríos, P., Vega, J., Menduiña, R., Blanco, J.F., Baena, J., Herrera, T., Petri, A., Gómez, J.L., 2008. Un espacio compartido por vivos y muertos: el poblado calcolítico de fosos de Camino de las Yeseras (San Fernando de Henares, Madrid). Complutum 19(1), 97-120.

Martín-Gil, J., Martín-Gil, F.J., Delibes-de-Castro, G. Zapatero-Magdaleno, P., SarabiaHerrero, J., 1995. The first known use of vermillion. Cell. Mol. Life Sci. 51, 759761.

Martínez-Fernández, M.J., Gavilán, B., Barrios, J., Montealegre, L., 1999. Materias primas colorantes en Murciélagos de Zuheros (Córdoba): caracterización y procedencia, in: Bernabeu, J., Orozco, T. (Eds.), II Congreso de Neolítico de la Península Ibérica. Saguntum (PLAV), Extra 2, 111-116.

Mazzocchin, G.A., Baraldi, P., Barbante, C., 2008. Isotopic analysis of lead present in the cinnabar of roman wall paintings from the Xth Regio "(Venetia et Histria)" by ICP-MS. Talanta 74, 690-693.

Mioč, U.B., Colomban, P., Sagon, G., Stojanović, M., Rosić, A., 2004. Ochre decor and cinnabar residues in neolithic pottery from Vinča, Serbia. J. Raman Spectrosc. 35, 843-846.

Mudarra, J.L., 1988. Reconocimiento de los suelos de la comarca de El Aljarafe (Sevilla). Instituto de Recursos Naturales y Agrobiología, Sevilla.

Murillo-Barroso, M., García Sanjuán, L. in press. El ámbar del PP4-Montelirio, in: García Sanjuán, L., Hurtado Pérez, V., Vargas Jiménez, J.M., Ruiz Moreno, T., Cruz-Auñón Briones, R. (Eds.), Valencina Prehistórica. Actas del Congreso Conmemorativo del Descubrimiento de La Pastora (1860-2010). Universidad de Sevilla, Sevilla.

Murillo-Barroso, M. Martinon-Torres, M. 2012. Amber Sources and Trade in the Prehistory of the Iberian Peninsula. Eur. J. Archaeol. 15, 187-216.

Nocete Calvo, F., Queipo de Llano, G., Sáenz, R., Nieto, J.M., Inácio, N., Bayona, M.R., Peramo, A., Vargas Jiménez, J.M., Cruz-Auñón Briones, R., Gil-Ibarguchi, J.I., Santos, J.F., 2007. The smelting quarter of Valencina de la Concepción (Seville, Spain): the specialised copper industry in a political centre of the Guadalquivir valley during the Third Millennium BC (2750-2500 BC). J. Archaeol. Sci. 35, 717-732.

Oka, R., Kusimba, C.M., 2008. The archaeology of trading systems, Part 1: Towards a New Trade Synthesis. J. Archaeol. Res. 16, 339-395. 
Piga, G., Santos-Cubedo, A., Brunetti, A., Piccinini, M., Malgosa, A., Napolitano, E., Enzo, S., 2011. A multi-technique approach by XRD, XRF, FT-IR to characterize the diagenesis of dinosaur bones from Spain. Paleogeogr. Paleoclimatol. Paleoecol. 310, 92-107.

Polvorinos del Río, A., García Sanjuán, L., Hernández, M.J., Almarza, J., 2001. Análisis arqueométrico de objetos cultuales prehistóricos hallados en Almadén de la Plata (Sevilla), in: Roldán, C. (Ed.), Actas del IV Congreso Nacional de Arqueometría. Universidad de Valencia, Valencia, pp. 321-327.

Ramos, J., Domínguez-Bella, S., Castañeda, V., Lazarich, M., Pérez, M., Morata, M., Martínez, C., Cáceres, I., Feliu, M.J., 1997. El dolmen de Alberite (Villamartín). Excavación, analítica y su aportación al conocimiento de las sociedades del $\mathrm{V}^{\mathbf{o}}$ milenio a.n.e. en el NE de Cádiz, in: Rodríguez Casal, A.A. (Ed.), O neolítico atlántico e as orixes do megalitismo: Actas do Coloquio Internacional (Santiago de Compostela, 1-6 de abril de 1996), Universidade de Santiago de Compostela, Santiago de Compostela, pp. 839-854.

Renfrew, C., 1969. Trade and culture process in European prehistory. Curr. Anthropol. $10,151-169$.

Roldán, C., Ferrero, J.L., García Borja, P., Domingo Sanz, I., 2008. Aportaciones al uso de pigmentos durante el Neolítico antiguo en las comarcas centrales valencianas, in: Rovira, S., García-Heras, M., Gener, M., Montero, I. (Eds.), Actas del VII Congreso Ibérico de Arqueometría, Madrid, pp. 669-679.

Rubio de Miguel, I., 1989. El Neolítico peninsular. Una interpretación de los datos arqueológicos. Cuadernos de Prehistoria y Arqueología de la Universidad Autónoma de Madrid 16, 11-41.

Sánchez Gómez, J., Mira Delli-Zotti, G., Dobado, R., 1997. La savia del Imperio. Tres estudios de economía colonial. Universidad de Salamanca, Salamanca.

Schwertmann, U., Cornell, R.M., 1991. Iron oxides in the laboratory. Preparation and characterization. $\mathrm{VCH}$, Weinheim.

Shoval, S., Beck, P. 2005. Thermo-FTIR spectroscopy analysis as a method of characterizing ancient ceramic technology. J. Therm. Anal. Calorim. 82, 609-616.

Spangenberg, J.E., Lavrič, J.V., Meisser, N., Serneels, V., 2010. Sulfur isotope analysis of cinnabar from roman wall paintings by elemental analysis/isotope ratio mass spectrometry - tracking the origin of archaeological red pigments and their authenticity. Rapid Commun. Mass Spectrom. 24, 2812-2816. 
Tornos Arroyo, F., 2008. La Geología y Metalogenia de la Faja Pirítica Ibérica. Macla $10,13-23$.

Torrent, J., Schwertmann, U., Fechter, H., Alferez, F., 1983. Quantitative relationships between soil color and hematite content. Soil Sci. 136(6), 354-358.

Vargas Jiménez, J.M., 2003. Elementos para la definición territorial del yacimiento prehistórico de Valencina de la Concepción (Sevilla). Spal 12, 125-144.

Vargas Jiménez, J.M., 2004. Carta Arqueológica Municipal de Valencina de la Concepción. Junta de Andalucía, Sevilla.

Wheatley, D., Strutt, K., García Sanjuán, L., Peinado Cucarella, J., Mora Molina, C., 2012. New evidence on the spatial organisation of the Valencina de la Concepción Copper Age settlement: the geophysics between La Pastora and Montelirio. Trabajos Prehist. 69(1), 65-79.

Wohlfarth, B., Skog, G., Possnert, G., Holmquist, B., 1998. Pitfalls in the AMS radiocarbon-dating of terrestrial macrofossils. J. Quat. Sci. 13(2), 137-145.

Zapatero P., 1989. La Velilla. Un enterramiento de tradición dolménica en el valle del Valdavia. Publicaciones de la Institución Tello de Meneses 60, 7-14.

Zilhão, J., Angelucci, D.E., Badal-García, E., d'Errico, F., Daniel, F., Dayet, L., Douka, K., Higham, T.F.G., Martínez-Sánchez, M.J., Montes-Bernárdez, R., MurciaMascarós, S., Pérez-Sirvent, C., Roldán-García, C., Vanhaeren, M., Villaverde, V., Wood, R., Zapata, J., 2010. Symbolic use of marine shells and mineral pigments by Iberian Neanderthals. Proc. Natl. Acad. Sci. USA 107(3), 1023-1028. 


\section{$\underline{\text { Figure Captions }}$}

Figure 1. Location of PP4-Montelirio sector of Valencina de la Concepción archaeological site.

Figure 2. Aerial view of 10042-10049 megalithic structure.

Figure 3. Lower depositional level of the second burial chamber of structure 1004210049.

Figure 4. Upper depositional level of the second chamber of structure 10042-10049.

Figure 5. XRD patterns corresponding to (a) sample O1-C1 showing the presence of cinnabar on the ceramic paste (b) sample ML-05 showing the presence of cinnabar on ivory surface.

Figure 6. XRD spectrum of samples (a) $\mathrm{O} 1-\mathrm{H} 1$; (b) $\mathrm{O} 1-\mathrm{H} 2$; and (c) $\mathrm{O} 2-\mathrm{H} 2$.

Figure 7. SEM images (a) pigments particles dispersed on the ceramic surface (b) the morphology detail of the cinnabar particle into the pottery (c) iron oxides crystals mixture with cinnabar particles over pottery (d) EDX spectra of the cinnabar and iron oxides pigments found into the pottery surface.

Figure 8. SEM images (a) showing a microbial biofilm developing over the osteonic compact ivory surface of sample $\mathrm{O} 1-\mathrm{H} 2$ (b) the morphology detail of the cinnabar particle embedded into the ivory surface (c) EDX spectra of the ivory surface and cinnabar particles found into the ivory.

Figure 9. $\mu$ XRF spectra comparison between pottery paste fragment and scrapping red stained over the pottery.

Figure 10. (a) SEM image showing a surface of the bone sample O2-H2 including a titanium crystal on the surface related to the clay sediments (b) EDX spectra of the bone surface including punctual analysis of the titanium crystals associated with rutile structure. 
Figure 11. (a), (c), (e) Optical images of the Raman measurements areas of the different samples (b) Raman spectra of cinnabar associated with the red pigment including phosphates related to the ivory and bone surfaces (d) and (f) Raman spectra of cinnabar associated with the red pigments over ivory and pottery.

Figure 12. FTIR spectra of the samples (a) pottery (b) bone and ivory. 
$\underline{\text { Tables }}$

Table 1. Samples studied in this work.

\begin{tabular}{|c|c|c|}
\hline Sample id. & Description & Archaeological context \\
\hline O1-H1 & Red stained ivory. Scrapings & SU 535; Structure 10049 \\
\hline $\mathrm{O} 1-\mathrm{H} 2$ & $\begin{array}{l}\text { Red stained ivory. } \\
\text { Fragment }\end{array}$ & SU 535; Structure 10049 \\
\hline $\mathrm{O} 1-\mathrm{C} 1$ & $\begin{array}{l}\text { Red stained pottery. } \\
\text { Scrapings }\end{array}$ & SU 535; Structure 10049 \\
\hline $\mathrm{O} 1-\mathrm{C} 2$ & $\begin{array}{l}\text { Red stained pottery. } \\
\text { Potsherd fragment }\end{array}$ & SU 535; Structure 10049 \\
\hline $\mathrm{O} 5-\mathrm{O}$ & Earth and red dust & SU 535; Structure 10049 \\
\hline $\mathrm{O} 3-\mathrm{C} 1$ & $\begin{array}{l}\text { Red stained pottery. } \\
\text { Potsherd fragment }\end{array}$ & SU 535; Structure 10049 \\
\hline $\mathrm{O} 3-\mathrm{C} 2$ & $\begin{array}{l}\text { Red stained pottery. } \\
\text { Scrapings }\end{array}$ & SU 535; Structure 10049 \\
\hline $\mathrm{O} 2-\mathrm{H} 1$ & $\begin{array}{l}\text { Red stained human bone. } \\
\text { Fragment }\end{array}$ & SU 664; Structure 10049 \\
\hline $\mathrm{O} 2-\mathrm{H} 2$ & $\begin{array}{l}\text { Red stained human bone. } \\
\text { Scrapings }\end{array}$ & SU 664; Structure 10049 \\
\hline $\mathrm{O} 4-\mathrm{C} 1$ & $\begin{array}{l}\text { Red stained pottery. } \\
\text { Potsherd fragment }\end{array}$ & SU 664; Structure 10049 \\
\hline ML02 & $\begin{array}{l}\text { Red stained ivory (carved } \\
\text { tusk). Scrapings }\end{array}$ & SU 535; Structure 10049 \\
\hline ML05 & $\begin{array}{l}\text { Red stained ivory (carved } \\
\text { tusk). Fragment }\end{array}$ & SU 535; Structure 10049 \\
\hline
\end{tabular}

SU: Stratigraphic Unit

Table 2. Elemental composition of the different samples studied throughout X-ray microfluorescence.

\begin{tabular}{|l|l|}
\hline Sample id. & Elemental composition $(\mu$-EDXRF) \\
\hline O1-H1 & $\mathrm{Ca}, \mathrm{Ti}, \mathrm{Fe}, \mathrm{Si}, \mathrm{P}, \mathrm{S}, \mathrm{K}, \mathrm{Fe}, \mathrm{Hg}$ \\
\hline O1-H2 & $\mathrm{Ca}, \mathrm{Ti}, \mathrm{Fe}, \mathrm{Si}, \mathrm{P}, \mathrm{S}, \mathrm{K}, \mathrm{Fe}, \mathrm{Hg}$ \\
\hline O1-C1 & $\mathrm{Na}, \mathrm{Al}, \mathrm{Si}, \mathrm{S}, \mathrm{K}, \mathrm{Ca}, \mathrm{Ti}, \mathrm{Mn}, \mathrm{Fe}, \mathrm{Zn}, \mathrm{Hg}$ \\
\hline O1-C2 & $\mathrm{Mg}, \mathrm{Al}, \mathrm{Si}, \mathrm{S}, \mathrm{K}, \mathrm{Ca}, \mathrm{Ti}, \mathrm{Mn}, \mathrm{Fe}, \mathrm{Zn}, \mathrm{Hg}$ \\
\hline O5-O & $\mathrm{Ca}, \mathrm{Ti}, \mathrm{Fe}, \mathrm{Mn}, \mathrm{Al}, \mathrm{Si}, \mathrm{P}, \mathrm{S}, \mathrm{K}, \mathrm{Ca}, \mathrm{Zn}, \mathrm{Hg}$ \\
\hline O3-C1 & $\mathrm{Al}, \mathrm{Si}, \mathrm{P}, \mathrm{S}, \mathrm{K}, \mathrm{Ca}, \mathrm{Ti}, \mathrm{Mn}, \mathrm{Fe}, \mathrm{Zn}, \mathrm{Hg}$ \\
\hline O3-C2 & $\mathrm{Al}, \mathrm{Si}, \mathrm{S}, \mathrm{K}, \mathrm{Ca}, \mathrm{Ti}, \mathrm{Fe}, \mathrm{Zn}, \mathrm{Hg}$ \\
\hline O2-H1 & $\mathrm{A} 1, \mathrm{Si}, \mathrm{P}, \mathrm{S}, \mathrm{K}, \mathrm{Ca}, \mathrm{Ti}, \mathrm{Mn}, \mathrm{Fe}, \mathrm{Zn}, \mathrm{Hg}$ \\
\hline O2-H2 & $\mathrm{A}, \mathrm{Si}, \mathrm{P}, \mathrm{S}, \mathrm{K}, \mathrm{Ca}, \mathrm{Ti}, \mathrm{Mn}, \mathrm{Fe}, \mathrm{Zn}, \mathrm{Hg}$ \\
\hline O4-C1 & $\mathrm{Al}, \mathrm{Si}, \mathrm{P}, \mathrm{S}, \mathrm{K}, \mathrm{Ca}, \mathrm{Ti}, \mathrm{Mn}, \mathrm{Fe}, \mathrm{Hg}, \mathrm{Zn}$ \\
\hline
\end{tabular}



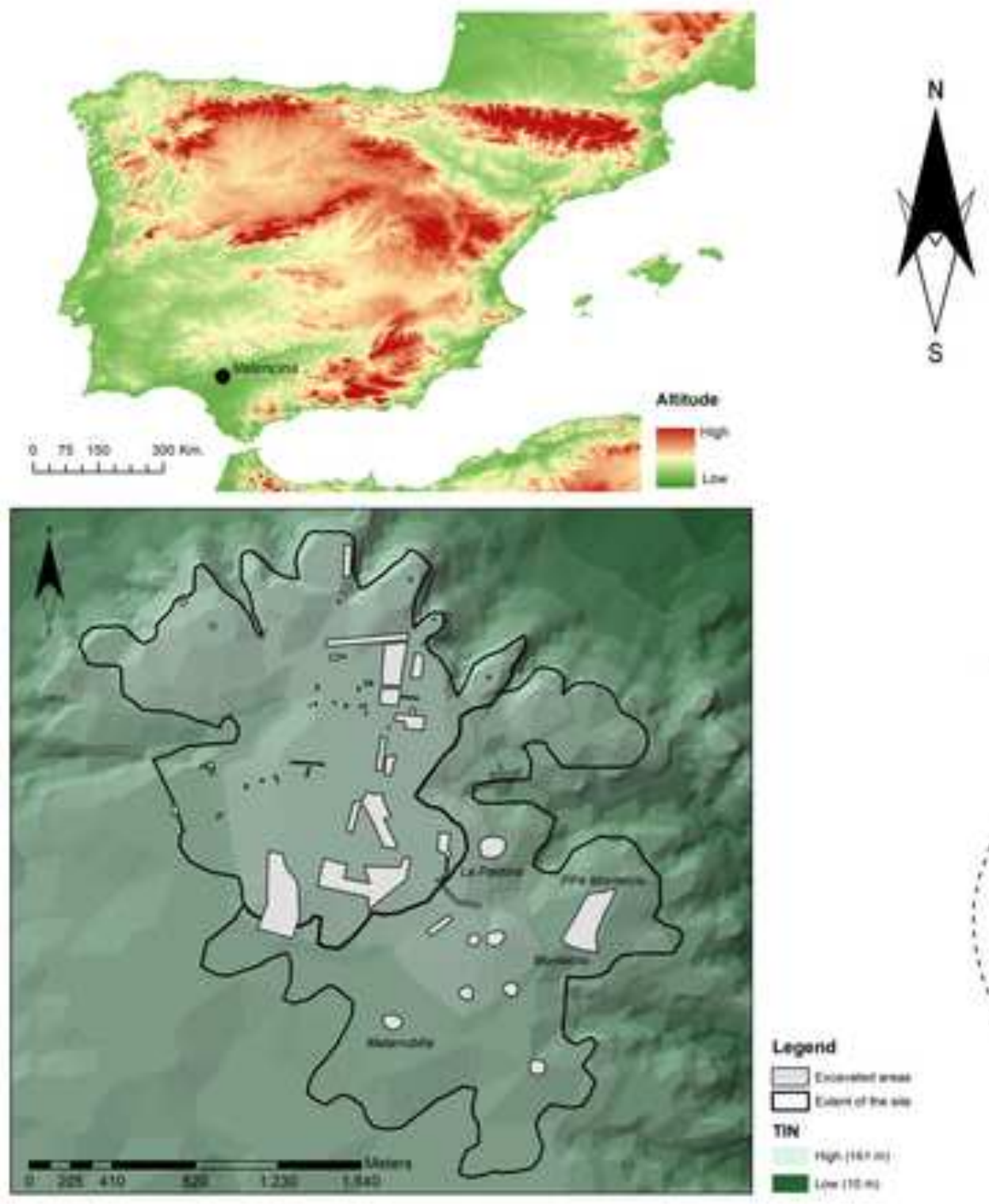

PP4-MONTELIRIO
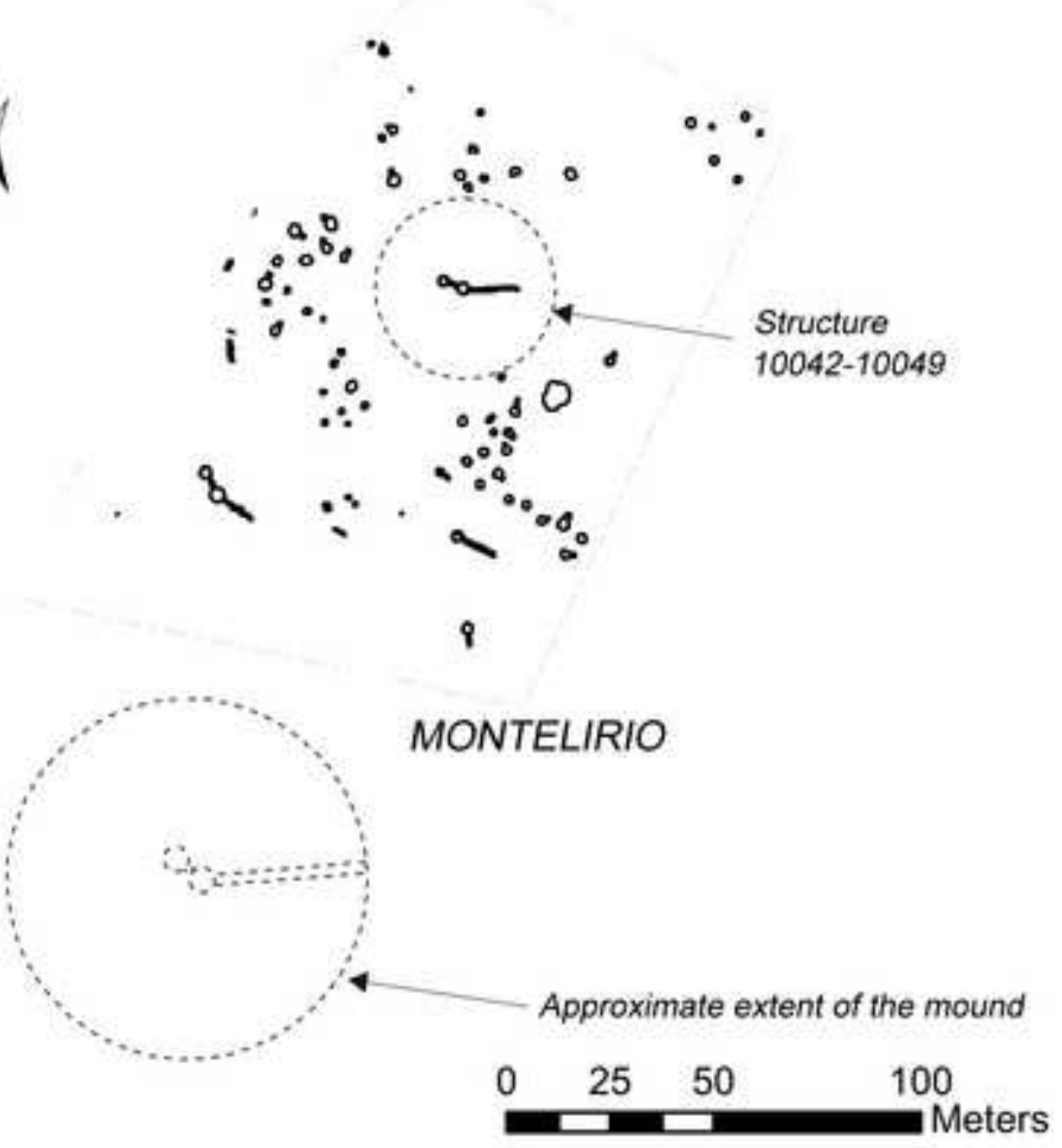


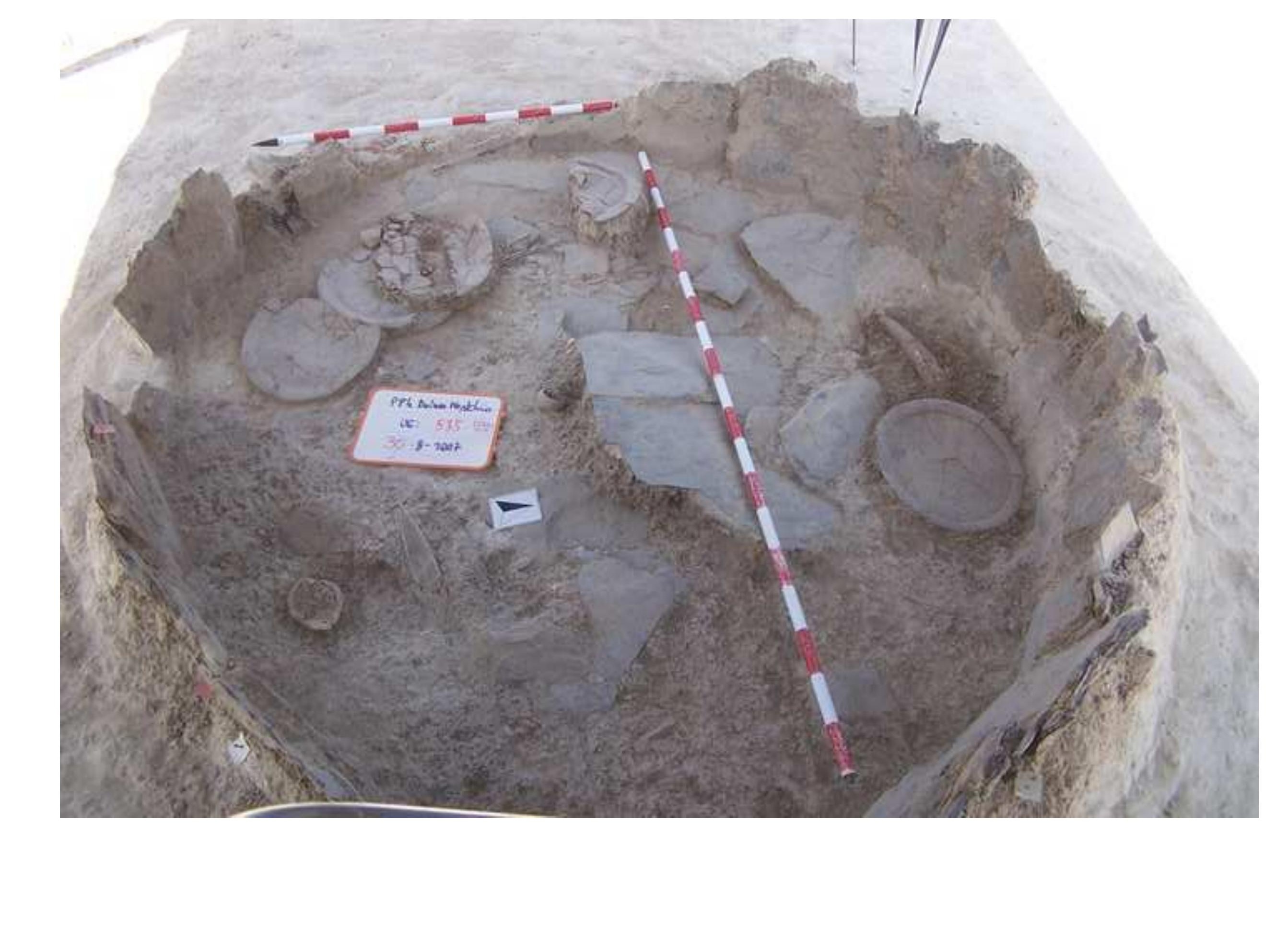

Figure

\section{4}
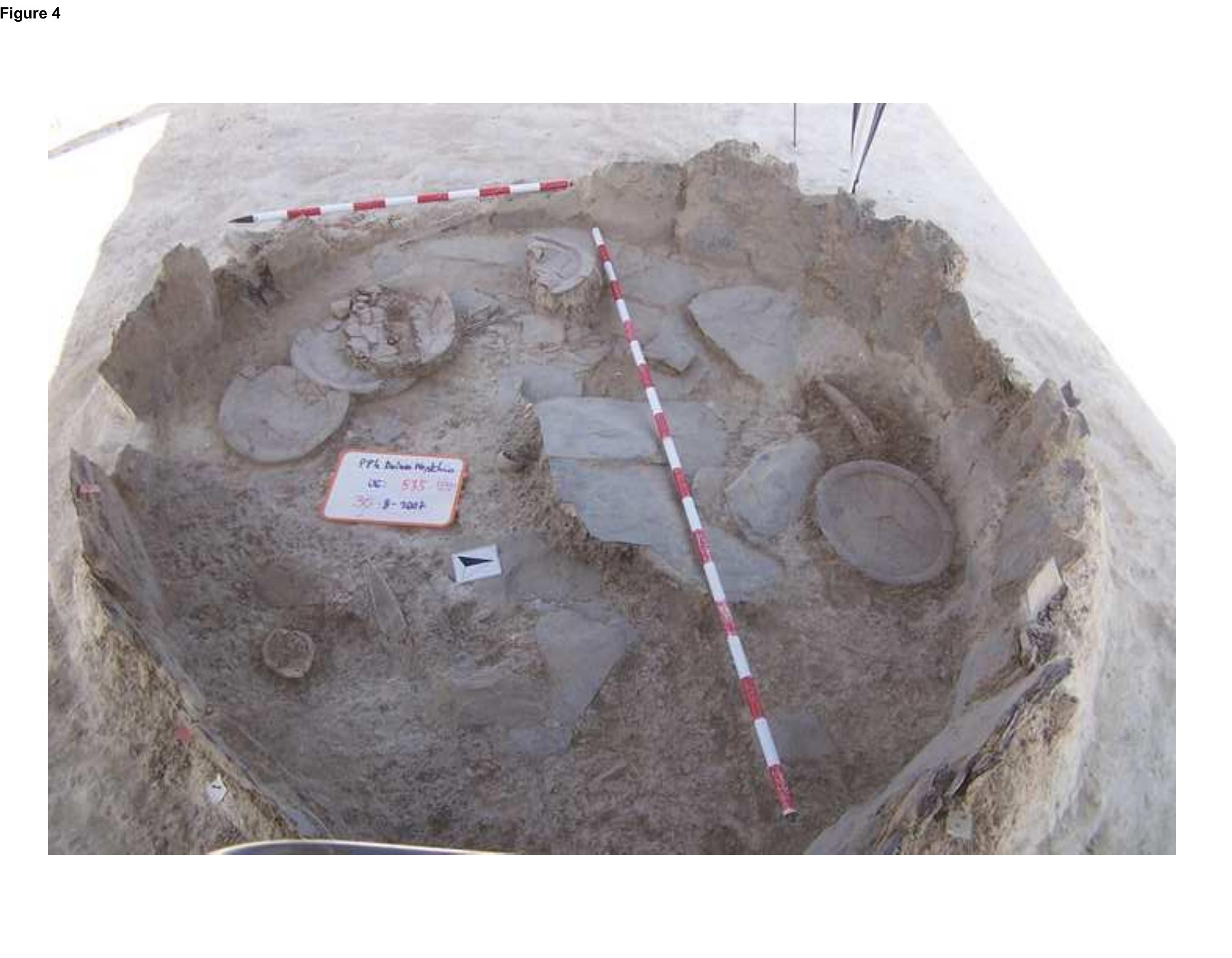


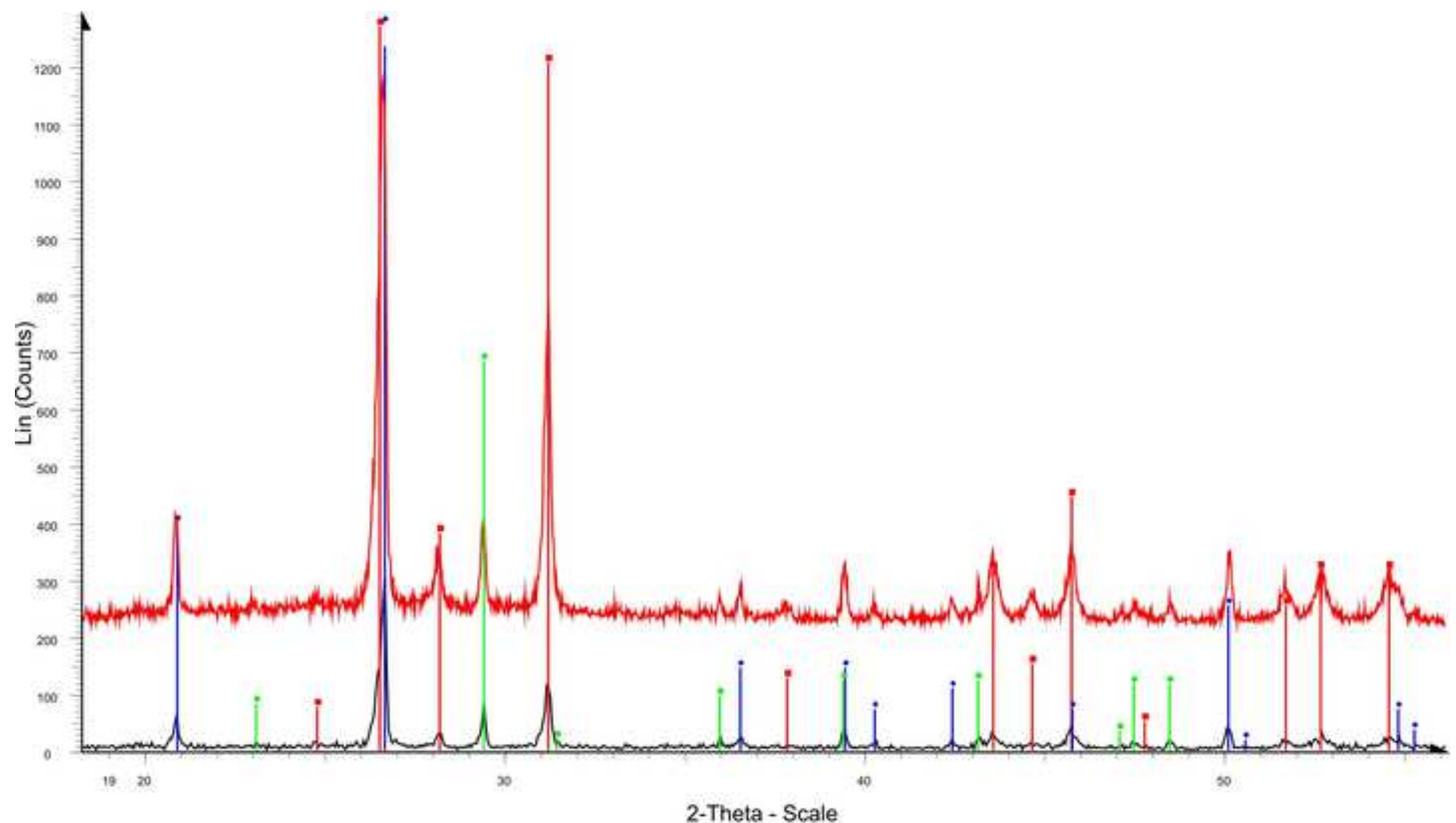

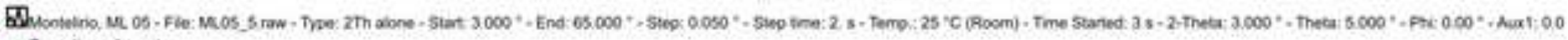

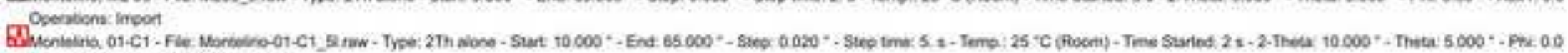
Opdestion: Y Scale Add 2 CO I Impon

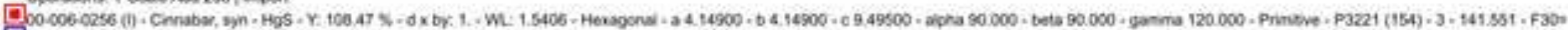

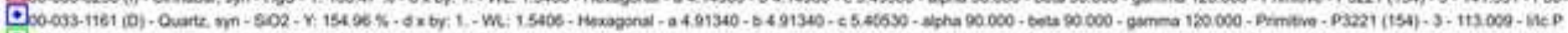

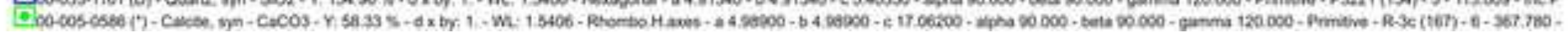




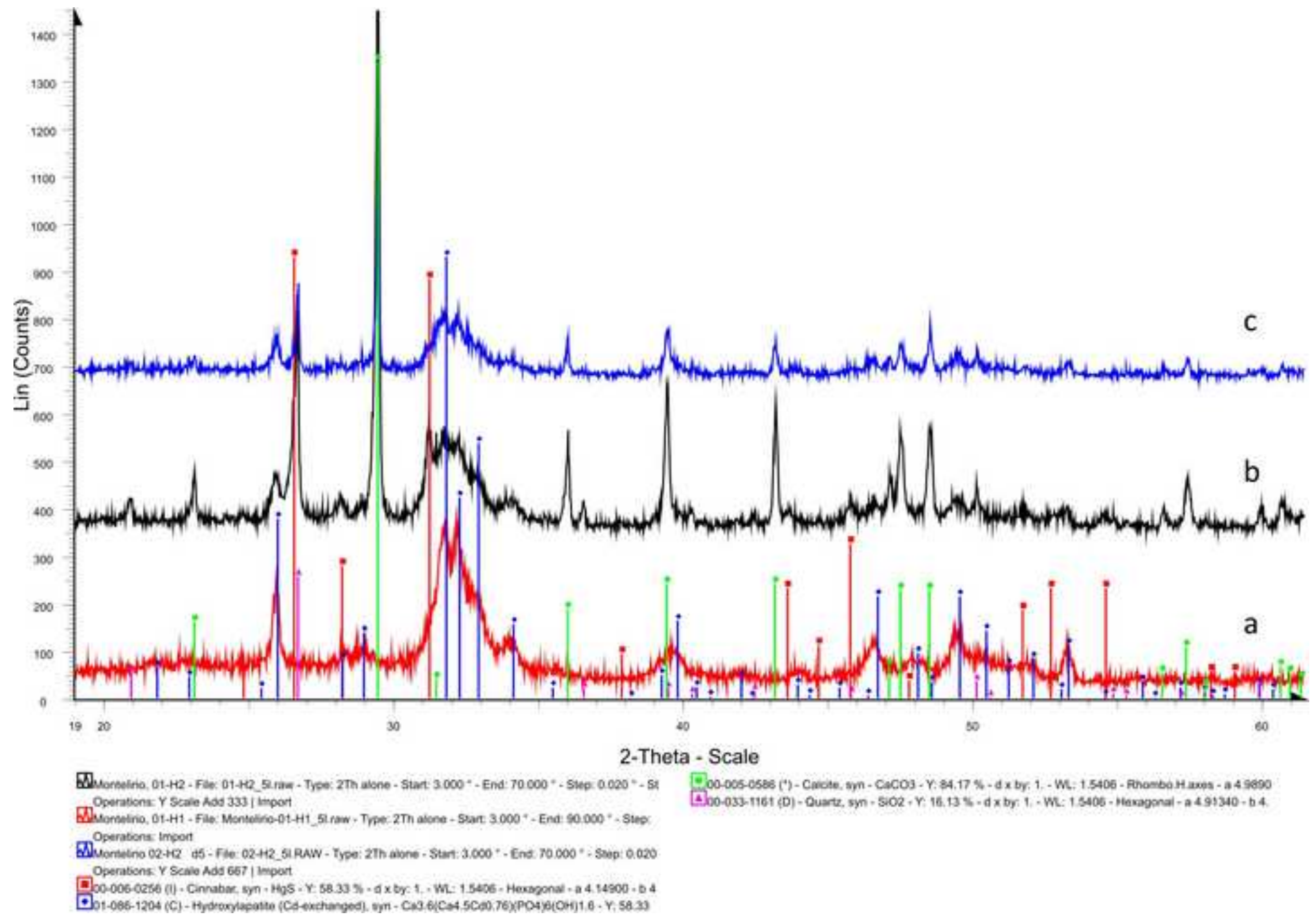



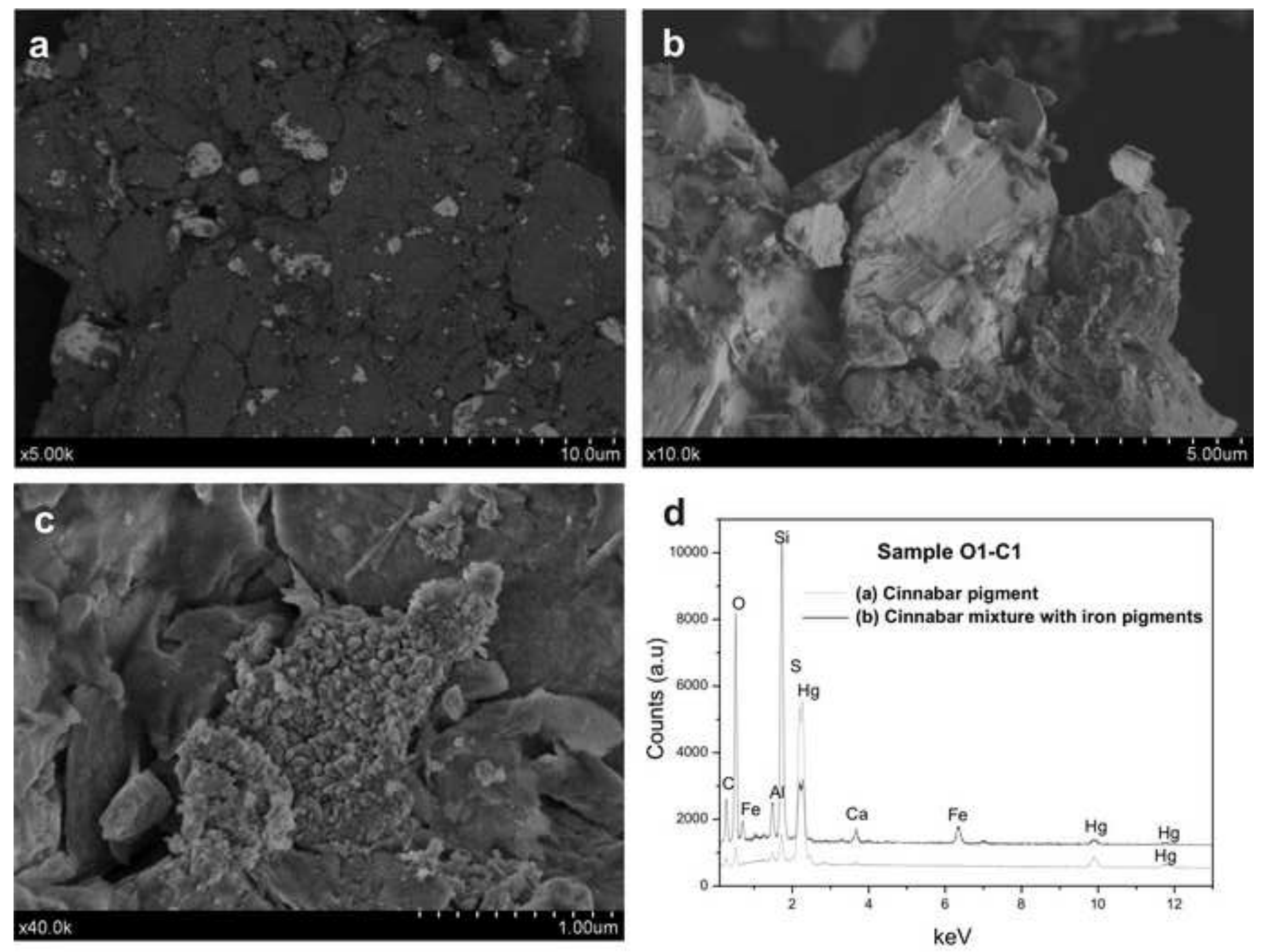


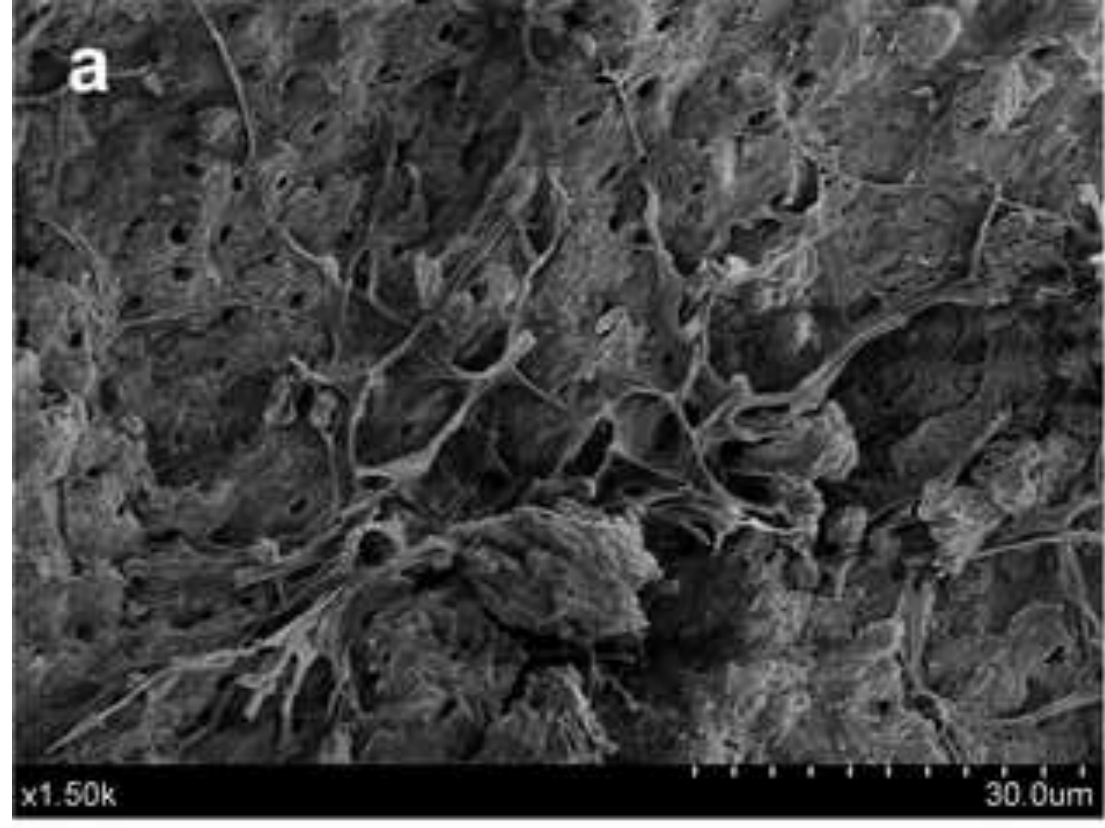

\section{C}

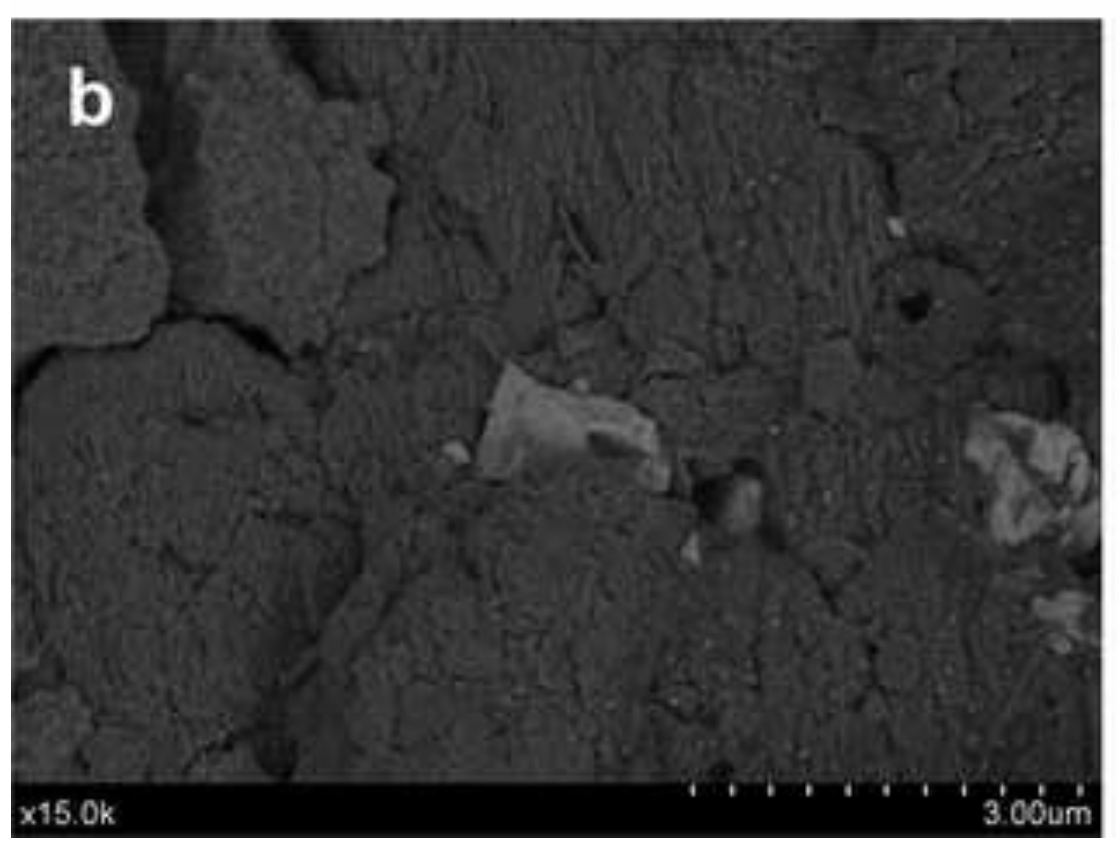

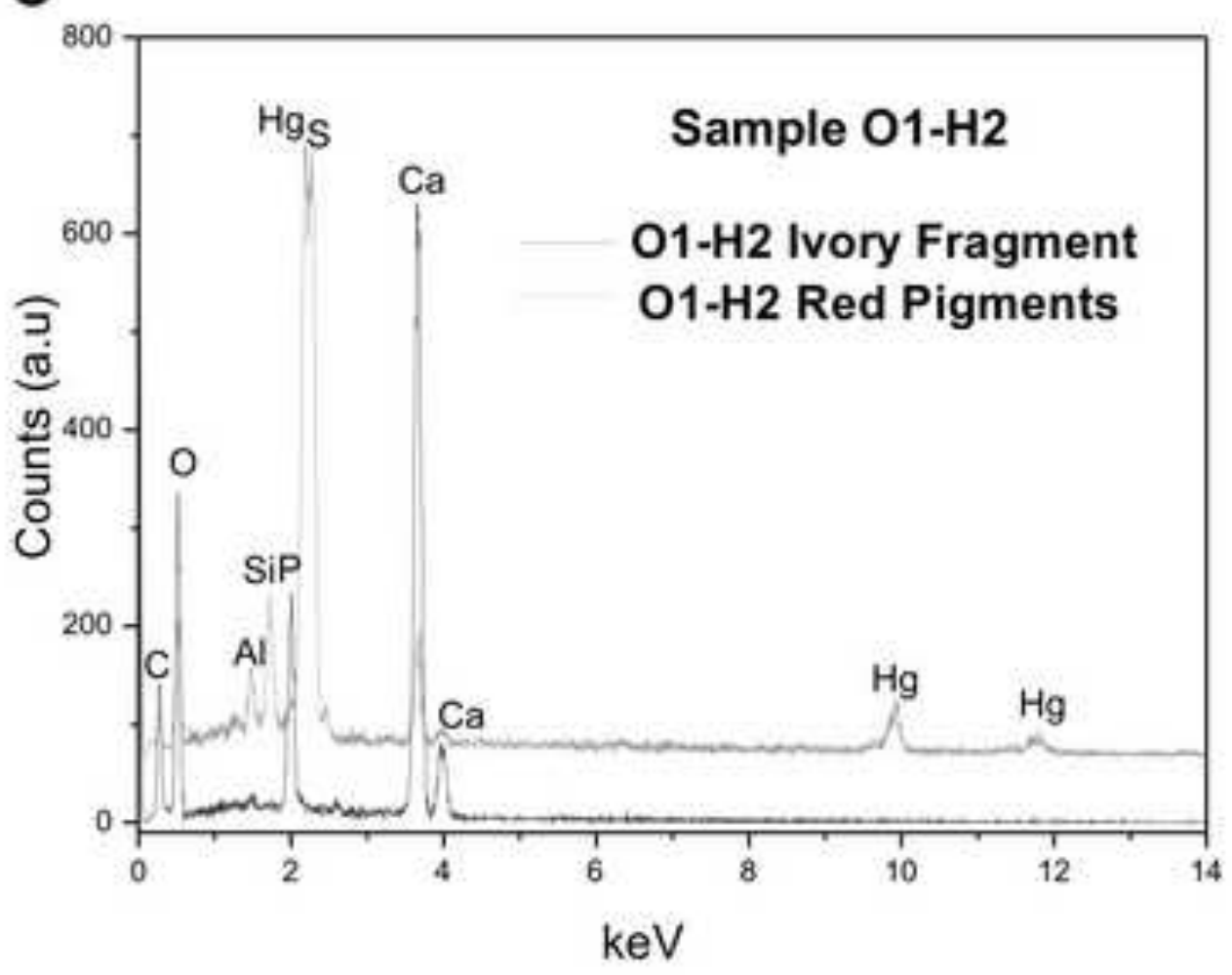




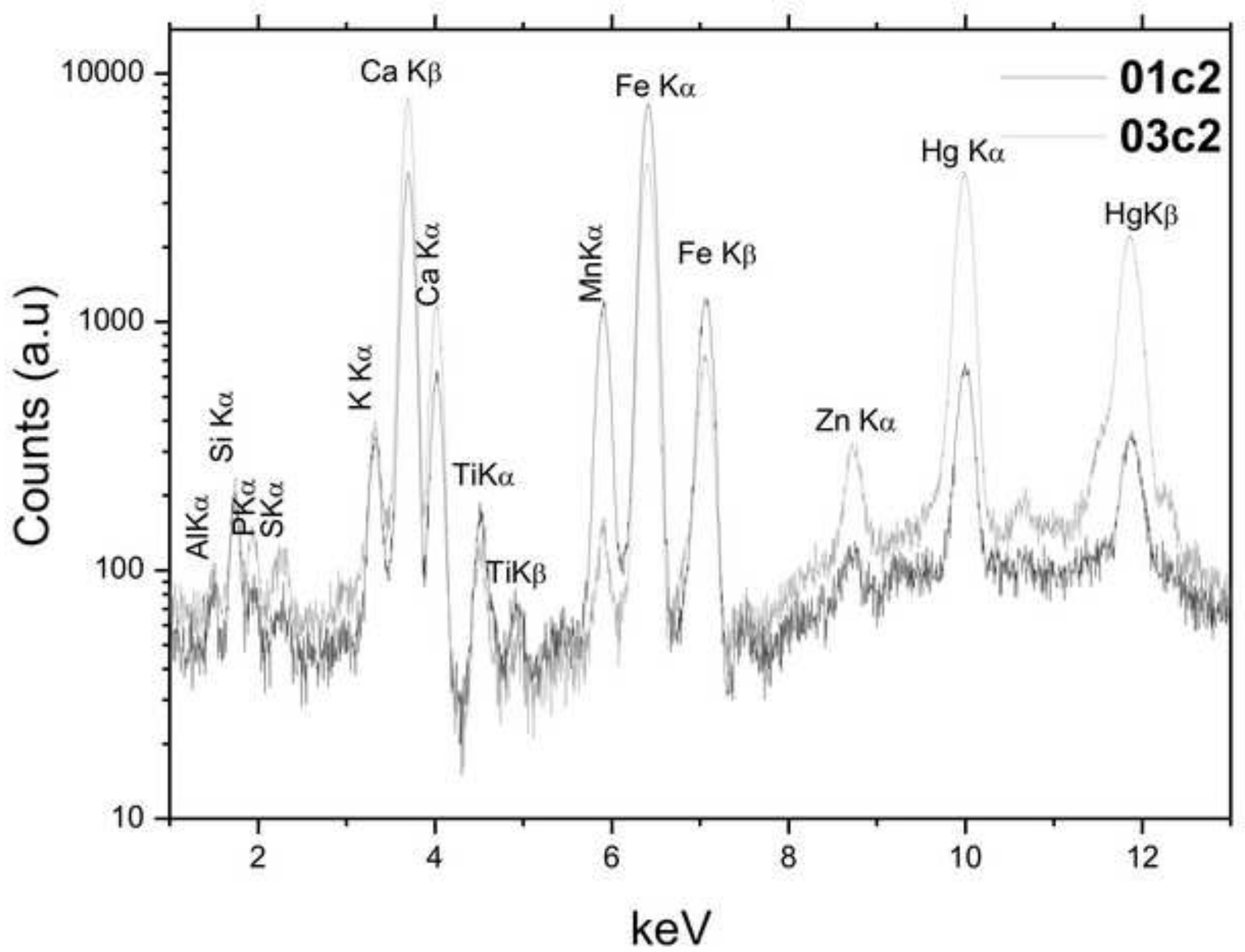


Figure 10

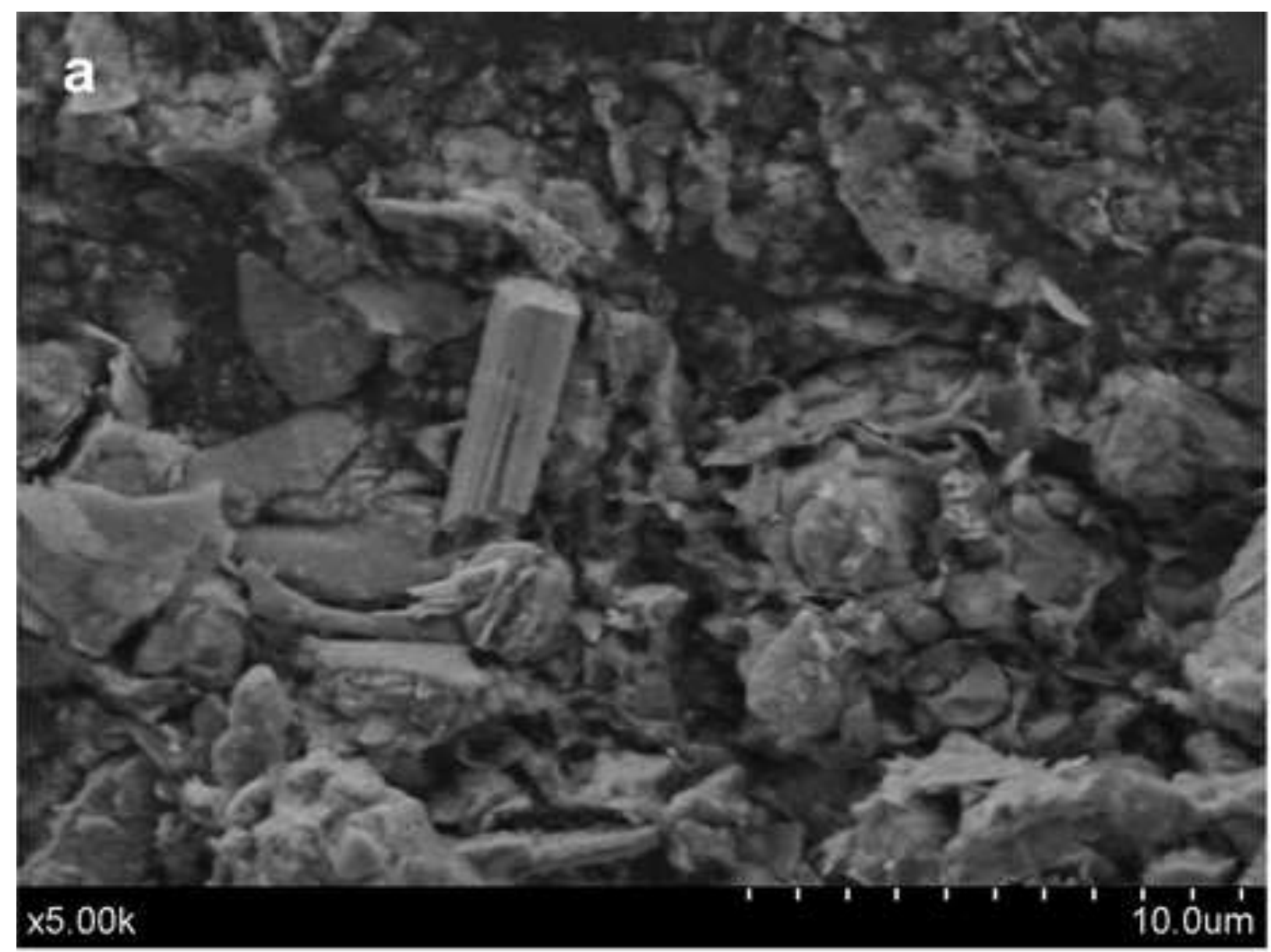

b

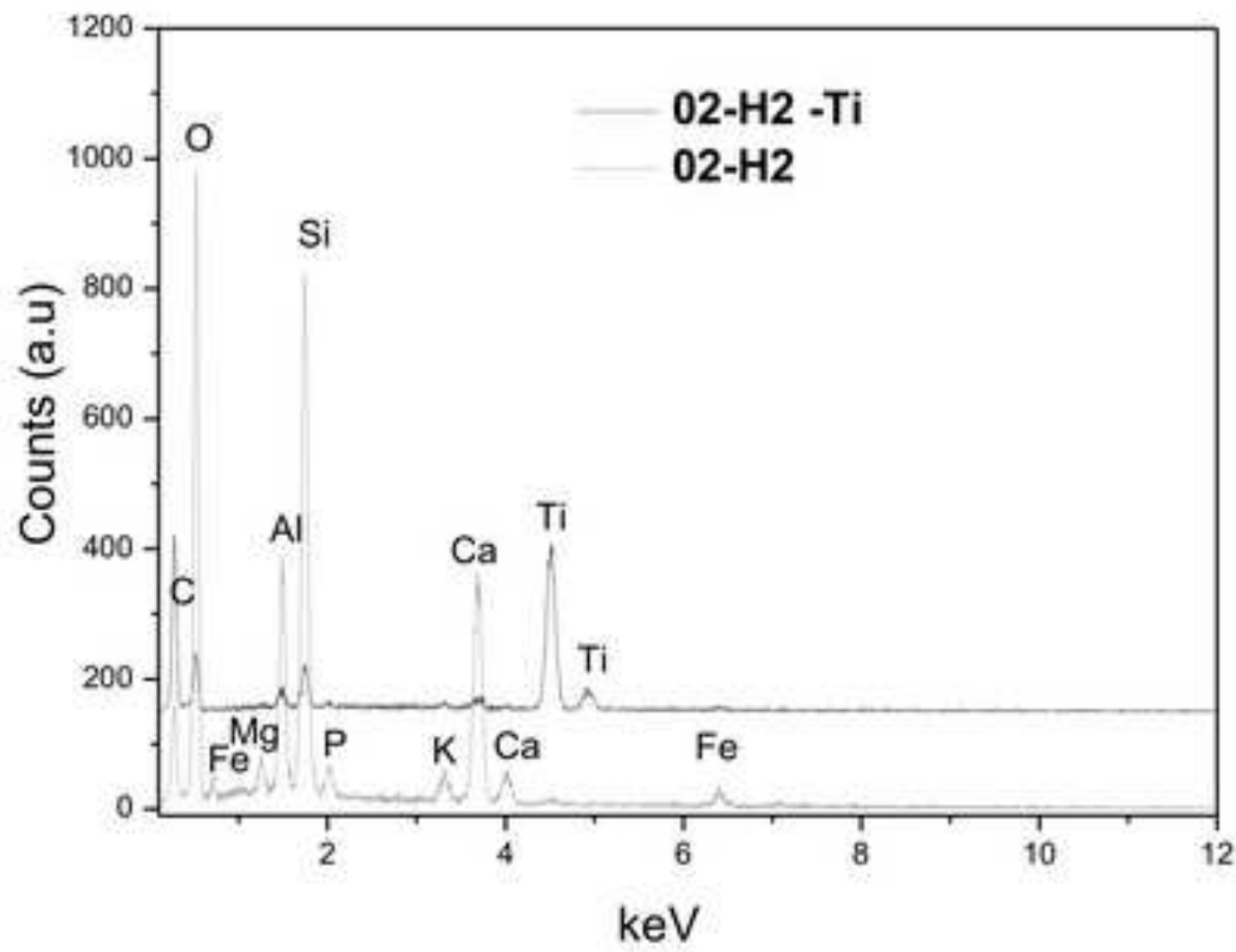

02- $\mathrm{H} 2-\mathrm{Ti}$

02-H2

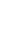



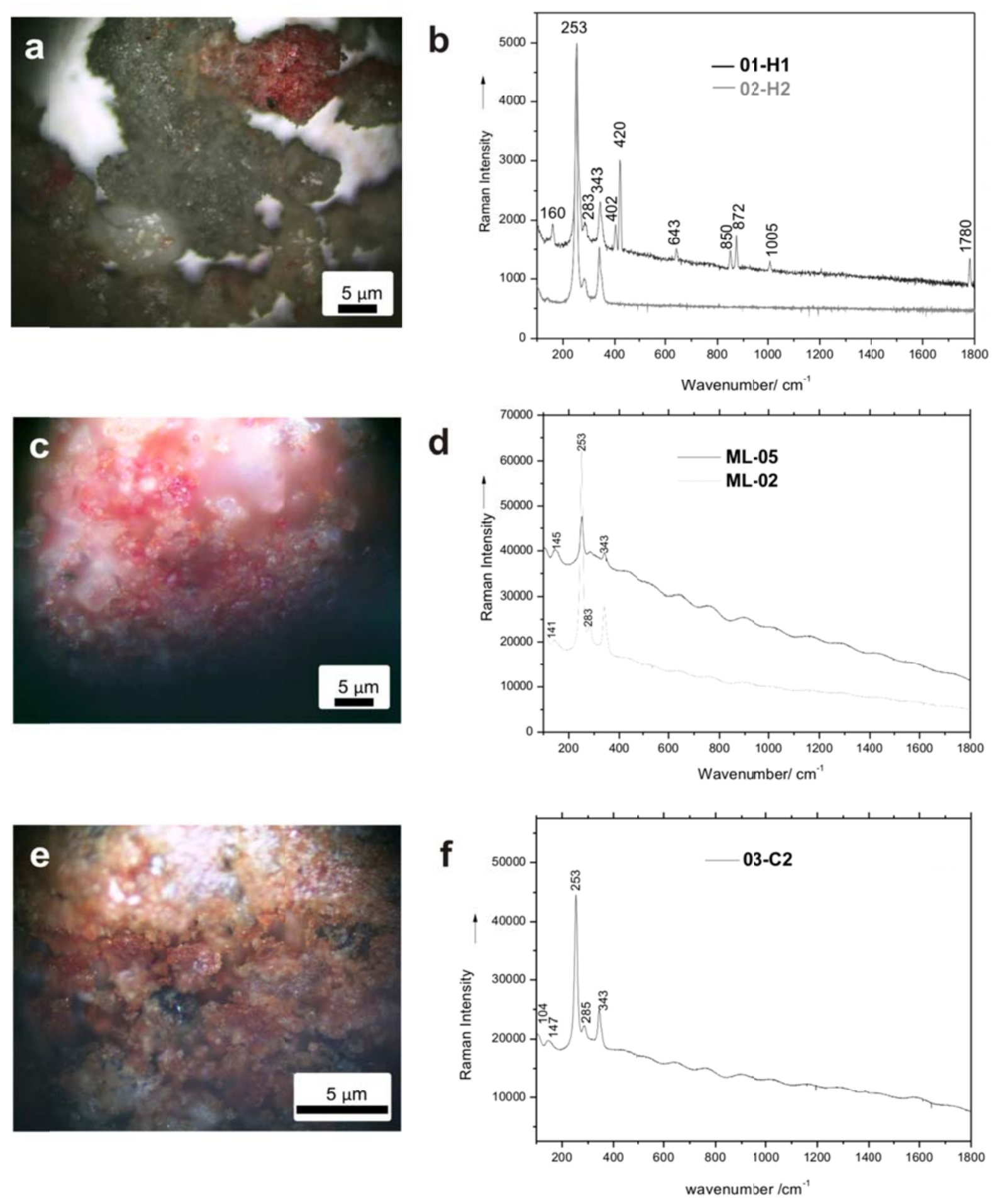

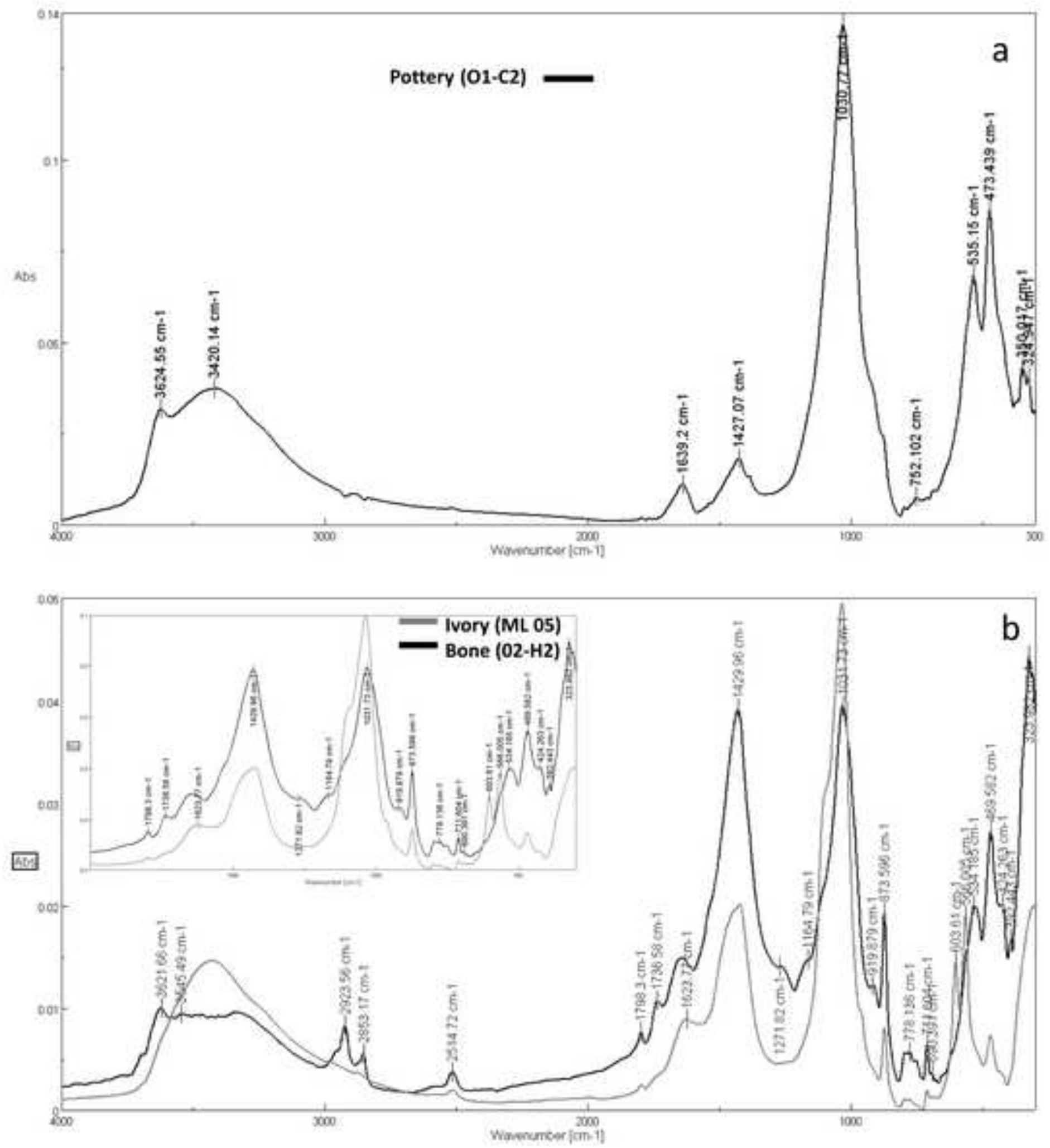